\title{
Readiness Analysis of Data Analytics Audit Implementation in Inspectorate General of the Ministry of Finance: An Indonesian Case
}

\author{
ALVAN CHAQIQI* \\ AGUNG NUGROHO \\ Polytechnic of State Finance STAN
}

\begin{abstract}
Organizations, including public sector organizations, are required to use data optimally. Unfortunately, only 9\% of organizations worldwide use data analytics properly (Meulen and McCall, 2018). The Ministry of Finance has many potential data and has initiated the audit data analytics scheme on the roadmap since 2019. This study aims to measure the readiness of audit data analytics implementation reviewed from general to specific by using a qualitative method where the informants were selected based on purposive sampling involving 20 speakers consisted of auditor, supporting unit, auditee, and expert. This study uses the primary model from Gürdür et al. (2019) based on the synthesis of the research study of Schuh et al. (2017) about the Industry 4.0 Maturity Index. Then, this model has been elaborated to generate four categories, eight aspects, and 15 criteria. These categories consist of resources readiness, information system readiness, culture readiness, and organizational readiness. The results show that the Ministry of Finance Inspectorate General has resources readiness at a high level and other categories at a medium level. Specifically, based on two most important activities involving data analytics in Inspectorate General, namely tax audit and financial statement review, show that tax audit has a high level of resource readiness, and the others at a medium level, meanwhile the financial statement review has a high level of resources readiness and information system readiness the others at a medium level. Gaps are caused by challenges both from internal and external organizations.
\end{abstract}

Keywords: Audit Data Analytics, Data Analytic Readiness, Inspectorate General

Abstrak: Setiap Organisasi termasuk organisasi sektor publik dituntut untuk memanfaatkan data secara optimal. Sayangnya, hanya 9\% organisasi di dunia yang telah menggunakan analisis data dengan baik (Meulen and McCall, 2018). Kementerian Keuangan memiliki banyak data potensial dan merupakan satu-satunya organisasi internal audit di Indonesia yang telah menginisiasi skema audit data analytics berupa roadmap tahun 2019. Penelitian ini bertujuan untuk mengukur kesiapan pelaksanaan audit data analytics ditinjau dari umum hingga khusus. Untuk mencapai tujuan tersebut, penelitian ini dilakukan dengan metode kualitatif dimana informan dipilih berdasarkan purposive sampling sejumlah 20 informan yang terdiri

\footnotetext{
* Corresponding author: alvan.chaqiqi@ kemenkeu.go.id

The author thanked the Inspectorate General of the Ministry of Finance and Polytechnic of State Finance STAN for granting the permit and support in the research process.
} 
dari auditor, unit pendukung, auditee, dan tenaga ahli. Penelitian ini menggunakan model utama dari Gürdür et al. (2019) berdasarkan sintesis studi penelitian Schuh et al. (2017) tentang Indeks Maturitas Industri 4.0. Model ini kemudian dijabarkan sehingga menghasilkan 4 kategori, 8 aspek, dan 15 kriteria. Kategori tersebut terdiri dari kesiapan Source daya, kesiapan sistem informasi, kesiapan budaya, dan kesiapan organisasi. Hasil penelitian menunjukkan bahwa secara umum, Inspectorate General of the Ministry of Finance memiliki kesiapan Source daya pada tingkat tinggi dan kategori lain pada tingkat menengah. Secara spesifik, berdasarkan dua aktivitas terbesar yang melibatkan data analytics di Inspektorat Jenderal, yaitu audit perpajakan dan reviu laporan keuangan, menunjukkan bahwa audit perpajakan memiliki tingkat kesiapan sumber daya yang tinggi dan yang lainnya pada tingkat sedang, sedangkan reviu laporan keuangan memiliki tingkat kesiapan sumber daya serta kesiapan sistem informasi yang tinggi, dan yang lainnya pada tingkat sedang. Kesenjangan disebabkan oleh tantangan baik dari internal maupun eksternal organisasi.

Kata Kunci: Audit Data Analytics, Kesiapan Data Analytics, Inspektorat Jenderal

\section{Introduction}

Industry 4.0 affects a wide range of work in a variety of fields, including accountants and auditors. Extracted from the World Economic Forum (2018) report, accountant and auditor jobs are predicted to decrease by $18 \%$ to $32 \%$ in 2022 as an industrial effect 4.0. Therefore, according to Daryanto (2019), the Government Internal Supervisory Apparatus (APIP) must adapt to anticipate disruptive risks to their profession and contribute more effectively in providing added value through information technology. The utilization of information technology will improve performance through automation in both the private and public sectors.

As a public sector organization, the Ministry of Finance of Indonesia Republic has a digital-based system with a massive database such as SPAN, SAKTI, MPN-G2, SIMPONI, SIMTRADA, and CEISA, which is the backbone in carrying out the duties and functions of managing the country's finances. However, based on the Inspectorate General document (2018) analysis, it is stated that so far, the utilization of existing data potential needs to be improved. One way to overcome it is through technology, both by manage ment and internal auditors. According to Lambrechts et al. (2011), organizations are unlikely to conduct effective audits without technology. Technology that can be utilized, for example, in the form of data analytics audit, which is a future audit scheme 
(Liddy, 2014). Data analytics can be used to run models or predictive analyses to assist auditors in identifying business risks during planning, detecting fraud, and helping evaluation (Liddy, 2014). Thus, according to Hiererra and Mario (2014), internal auditors are supposed to be continuous learners and preparing themself to face the business needs in the future. Furthermore, auditors are faced with the challenge of advanced analytical skills that allow auditors to perform detection, preventive, and prescriptive measures (Daryanto, 2019).

The Inspectorate General of the Ministry of Finance initiated data analytics through the data analytics roadmap in 2019. Previously, the utilization of information has been undertaken since 2009 with the approach of Computer-Based Audit Techniques (CAAT), Audit Command Language (ACL) application, and $\mathrm{CCH}$ Teammate Audit Management System (AMS) application. In 2014 the Inspectorate General continued to implement the Continuous Audit approach. The Inspectorate General has issued a Decree of the Inspector General No. 161/IJ.1/2019 dated June 12, 2019, concerning roadmap for the Implementation of Data analytics (DA) from 2019 to 2023. Based on the Inspector General's Decision, the data analytics roadmap is divided into three main phases, namely the preparation phase (2019 to 2020), the initiation phase (2020 to 2021), and the implementation phase (2022 to 2023). Data analytics is an ongoing and more profound step in the continuous audit process. Andriansyah (2019) stated that there is still a gap in the implementation of continuous audits, such as the human resources aspect that shows the uneven competence of auditors both within the number and the level of expertise. Furthermore, from the technology aspect, he also mentions the lack of standard quality and data access and technical aspects such as the lack of evaluation documentation of the continuous audit roadmap. The gap is a significant challenge in a data analytics audit scheme based on the initial interview with the team leader drafting the data analytics roadmap.

Data analytics is still a hot issue in the international world and has a fundamental level of problems. According to Katz (2014) and Whitehouse (2014) in Earley (2015), based on trends, the development of data analytics is slower than other best practices in the world of audits such as consulting and forensic auditing. Based on assessments 
conducted by Meulen dan McCall (2018), as shown in Figure I, from a survey of 196 international organizations, the average maturity level of data analytics is at level 3, and only $9 \%$ of organizations in the world are at level 5 . The survey illustrates the maturity level of data analytics implementation in the context of management decision-making. The discussion of data analytics became a fundamental issue, so that it has become the primary topic discussed in the 2019 inspectorate general's working meeting.

Figure 1.

Maturity Level of Data Analytics Implementation in the World

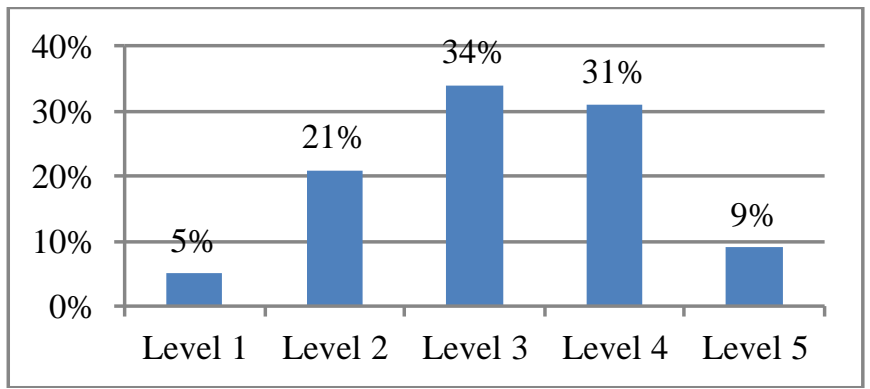

Source: (Meulen dan McCall, 2018)

The needs of the organization, current issues, gaps over the previous roadmap, problems in previous research, existing challenges become a motivation for the author to learn deeper the topic related to the readiness of data analytics audit. The main question in this study is "How is the readiness to implement data analytics audit in the Inspectorate General of the Ministry of Finance?". In addition to these critical questions, this study also analyzes urgency, policy models, gaps that occur and looks for better solutions. Eventually, It will accelerate implementation, socialization facilities, and evaluation materials for data analytics audits within the Inspectorate General of the Ministry of Finance. Furthermore, it is expected to improve internal audits and Governance Risk and Control (GRC) efficiency and become a benchmark for other internal audit organizations in developing data analytics audits

\section{Theoretical Framework}

\subsection{Agency Theory}

Berle and Means first introduced agency theory in 1930, stating that agents are not always converging with the principal's wishes (Auronen, 2003). Furthermore, agency 
theory was further developed by Jensen and Meckling in 1976 (Godfrey et al., 2010). In agency theory, relationships arise when there are cons between one party (agent) and the other party (principal). That is because management as an agent has more information than the principal called asymmetry information. The existence of asymmetry information causes the emergence of additional costs in agency costs (Godfrey et al., 2010). As illustrated in figure 2, an internal audit is one of the mechanisms to overcome agency problems in the public sector.

Figure 2.

Public Sector Agency Theory

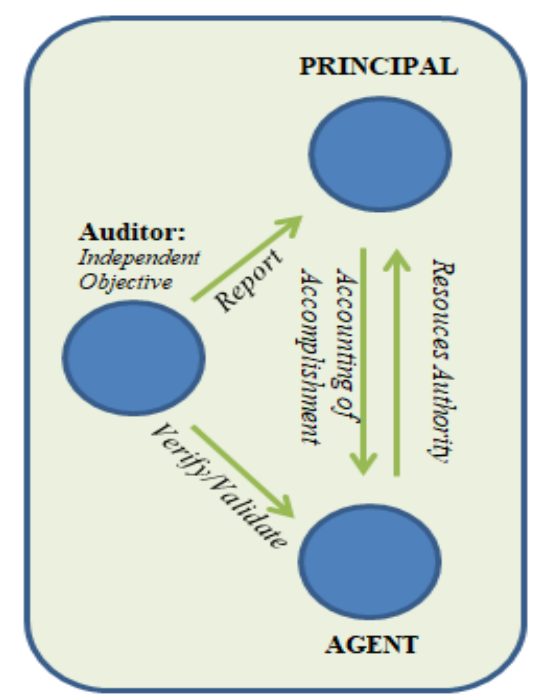

Source: (Goodson, Kenneth, dan Jacques, 2012)

Based on figure 2 and opinions from Kogan, Sudit, dan Vasarhelyi (2018), the role of auditors is to be a liaison between echelon I units of the Ministry of Finance as agents and the public as principals to reduce agency problems. Information technology allows auditors to be more advanced in projecting audit risk and increasing the frequency of audits as analysis becomes faster. Increasing the frequency of audits can reduce information asymmetry and even eliminate agency problems.

\subsection{Audit Data Analytics}

Russom (2011) defines big data as a merger of extensive data in various forms through a wide variety of analysis tools. Mayinka (2011) re-affirmed that big data is a 
measure of data beyond the software's ability to analyze. According to Chen et al. (2012), data analytics is a crucial area of magnitude, impact, and data-related problems that organizations must solve today. International Auditing and Assurance Standards Board's IAASB (2017) formulates the definition of data analytics in audit terminology as a science and art to find and analyze patterns and extract information and data (which become objects of supervision) through analysis, modeling, and visualization for audit purposes.

How organizations perform data analytics can be categorized into three levels: descriptive, predictive, and prescriptive (Earnshaw, Dill, dan Kasik, 2019). The descriptive analysis uses past reports to describe the conditions that occurred and answer the question "What happened?". At the predictive level, the analysis extracts information from large volumes of existing data, applies certain assumptions, and draws correlations to answer the question "What will happen?". At the prescriptive level, it requires a large volume of data to make predictions and connect them with actions that can produce the best outcome to answer the question "What should we do?".

The urgency of data analytics audit is stated by Lambrechts et al. (2011) in Global Technology Audit Guide (GTAG 16) that internal audits are required to provide added value to organizations through risk-based assurance, advice, and insight. IIA (2016) has explicitly poured the urgency of data analytics auditing through the emphasis of the word "must" in paragraph 1220.A2, which reads, "In exercising due to professional care internal auditors must consider the use of technology-based audit and other data analysis techniques."

\subsection{Theory of Readiness}

According to Armenakis, Harris, dan Mossholder (1993), the definition of readiness is a cognitive signal in the form of rejection behavior or support for a change. Readiness for applying data analytics was studied by Gürdür et al. (2019) using the readiness framework from Schuh's research study on Industrie 4.0 Maturity Index (Schuh et al., (2017)). 
Table 1.

Analytics Data Readiness Criteria

\begin{tabular}{|c|l|c|l|}
\hline No & \multicolumn{1}{|c|}{ Category } & \multicolumn{2}{|c|}{ Description } \\
\hline \multirow{2}{*}{1} & \multirow{2}{*}{$\begin{array}{l}\text { Resources } \\
\text { Readiness }\end{array}$} & a. & $\begin{array}{l}\text { The organization has a special division of data analytics and } \\
\text { employees who in charge of data analytics. }\end{array}$ \\
\cline { 3 - 5 } & b. & $\begin{array}{l}\text { The organization has techniques and technologies to analyze } \\
\text { data. }\end{array}$ \\
\cline { 3 - 5 } 2 & $\begin{array}{l}\text { c. } \\
\text { Information } \\
\text { Systems } \\
\text { Readiness }\end{array}$ & a. & $\begin{array}{l}\text { The organization has the resources to implement it } \\
\text { analytics. }\end{array}$ \\
\hline & b. & Employees can access reliable data \\
\hline \multirow{2}{*}{3} & $\begin{array}{l}\text { Cultural } \\
\text { Readiness }\end{array}$ & a. & Employees believe that data analytics is vital for work. \\
\cline { 3 - 5 } & $\begin{array}{l}\text { Organizational } \\
\text { readiness }\end{array}$ & $\begin{array}{l}\text { Employees believe that data analytics is essential for } \\
\text { organizations }\end{array}$ \\
\hline
\end{tabular}

Source: (Gürdür et al., (2019)

The author uses Gürdür's analytics data readiness criteria as the primary reference and merges them with the breakdowns from the synthesis of several other journals related to data analytics audits and the Inspectorate VII Inspectorate General study document. The result is shown in table 2. Furthermore, readiness level is measured by a particular scale described in table 3.

Table 2.

The Theory of Readiness in This Study

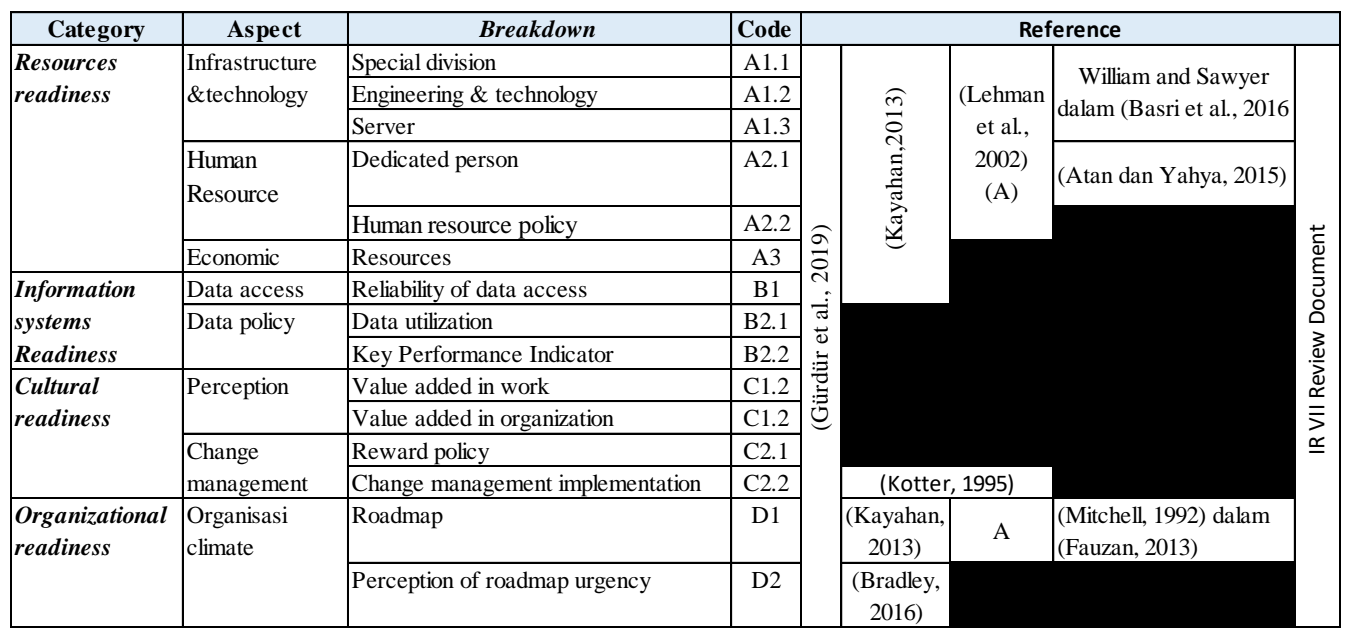

Source: Processed by Author 
Table 3.

Readiness Measurement Conversion

\begin{tabular}{|l|c|c|}
\hline Average Score & Alignment assessment & Readiness level \\
\hline $0 \%-20 \%$ & Very low & 1 \\
\hline $21 \%-40 \%$ & Low & 2 \\
\hline $41 \%-61 \%$ & Medium & 3 \\
\hline $61 \%-80 \%$ & High & 4 \\
\hline $81 \%-100 \%$ & Very High & 5 \\
\hline
\end{tabular}

Source: (Gürdür et al., (2019)

\subsubsection{Resources Readiness}

According to Gürdür et al. (2019), resource readiness is assessed based on three aspects: infrastructure and technology, human resources, and power sources. According to Lehman et al. (2002), infrastructure readiness can be measured based on the availability of computers and the ease of access. Furthermore, Kayahan (2013) explained that web servers and systems are required with sufficient accuracy, security, data integrity in the development of big data analytics. While William and Sawyer in Basri et al. (2016) stated that infrastructure is needed to develop, change, store, and process communication and information in the organization. Furthermore, Gürdür et al. (2019) explained that organizations need to have a special division that handles data analytics and technology to analyze data. Thus, it can be concluded that the readiness of infrastructure can be assessed from the existence of special divisions, techniques, and technologies, including servers and adequate infrastructure.

From the aspect of human resources' readiness, according to Lehman et al. (2002), can be measured from the sufficiency of reliable employees, availability of training for employee development, and learning motivation. Furthermore, Kayahan (2013) explained that human resources need to be trained with technological skills in performing audits, such as analyzing internal controls and seeing irregularities. In comparison, Atan dan Yahya (2015) stated that employee behavior affects the organization's readiness. Furthermore, according to Gürdür et al. (2019), one of the indicators for human resources' readiness is a dedicated employee to perform a data analytics audit. Thus, it can be concluded that the readiness of human resources can be 
evaluated from the availability of reliable employees (dedicated) and human resources development policy.

From the economic side, according to Kayahan (2013), organizations need to calculate the cost and benefits of initiating data analytics audits due to the high cost of investment. So it can be concluded that the organization's readiness in terms of economy is departed from the budget and cost and benefit analysis. In line with that, According to Gürdür et al. (2019), the indicator of economic readiness for data analytics is the availability of financial resources.

\subsubsection{Information Systems Readiness}

According to Gürdür et al. (2019), data analytics's information system readiness indicators are data accessibility and specific policies related to data analytics. According to Kayahan (2013), data accessibility is defined as complete and accurate data access with certain limitations to minimize unauthorized access.

\subsubsection{Cultural Readiness}

According to Gürdür et al. (2019), cultural readiness indicators to implement data analytics audits consist of employee awareness of the data analytics audits' importance for work and organization.

\subsubsection{Organizational readiness}

According to Mitchell in Fauzan (2013), organizational readiness can be measured from an organizational commitment to provides satisfaction and status for individuals. Lehman et al. (2002) explained the importance of the organization's climate in clarity of vision and mission, trust and mutual support between staff, and openness to change. It is supported by Kayahan (2013) that the organization must have a commitment and financial support. Furthermore, according to Gürdür et al. (2019), the indicator of organizational readiness is derived from the trust in the urgency of the existing roadmap. According to Stippitch and Bradley (2016), organizations need to create specific policies related to data analytics audits. 


\section{Research Method}

This paper is based on applied research using a qualitative method approach. According to Sugiyono (2014), qualitative research produces descriptive information and thoroughly describes the object's condition being studied. The object of this research is the Inspectorate General of The Ministry of Finance, specifically with two necessary business processes related to data analytics: tax audits and review of financial statements. Tax audit, which is the task of the Inspectorate I function, was chosen because it has considerable data potential. Meanwhile, the review of financial statements, which is the duty of Inspectorate VI, was chosen because it plays the role of financial accountability. In addition, both aspects have different maturity rates of Continuous Audit (CA) data analytics based on the Inspectorate General's internal reports. Scopes and variables, and detailed code are presented to facilitate data processing (Table 4).

Table 4.

Research Design

\begin{tabular}{|c|c|c|c|}
\hline \multicolumn{2}{|r|}{ Scope of Research } & \multicolumn{2}{|c|}{ Variables and Code } \\
\hline \multirow{2}{*}{\multicolumn{2}{|c|}{ Urgency of Applying }} & $\begin{array}{l}\text { General Understanding (UR- } \\
\text { 1) }\end{array}$ & Related Parties (UR-3) \\
\hline & & $\begin{array}{l}\text { Reason for Implementation } \\
\text { (UR-2) }\end{array}$ & Value Added (UR-4) \\
\hline \multicolumn{2}{|c|}{ Policy Model } & Policy Model (KK-1) & Correlation Method (KK-2) \\
\hline \multirow{4}{*}{ 离 } & \multirow{4}{*}{$\begin{array}{l}\text { General (KEU) } \\
\text { Tax Audit (KE1) } \\
\text { Review of Financial } \\
\text { Report (KE6) }\end{array}$} & $\begin{array}{l}\text { Infrastructure \&Technology } \\
\text { (KEU/1/6-1) }\end{array}$ & Policy (KEU/1/6-5) \\
\hline & & $\begin{array}{l}\text { Human Resources } \\
(\text { KEU/1/6-2) }\end{array}$ & $\begin{array}{l}\text { Perception \& Change } \\
\text { Management (KEU/1/6-6) }\end{array}$ \\
\hline & & Economic (KEU/1/6-3) & Climate Organization \\
\hline & & Data Access (KEU/1/6-4) & $(\mathrm{KEU} / 1 / 6-7)$ \\
\hline \multirow{2}{*}{\multicolumn{2}{|c|}{ Challenges and Strategies }} & Challenges (TS-1) & Current Efforts (TS-3) \\
\hline & & $\begin{array}{l}\text { Reason for the Challenge } \\
\text { (TS-2) }\end{array}$ & Next Strategy (TS-4) \\
\hline
\end{tabular}

Source: Processed by Author

The source data for this study consist of primary data and secondary data. Primary data are derived from interviews or reports containing raw data, while secondary data are extracted from literature studies and report results. The determination of informants 
is done purposively amounting to 20 (twenty), as shown in Table 6, to obtain a comprehensive perspective related to data analytics audit.

Table 5.

Research Informants

\begin{tabular}{lc}
\hline \multicolumn{1}{c}{ Position } & Amount \\
\hline Academics & 1 \\
\hline Technical Controllers & 2 \\
\hline Team Head Auditor/Section Head/Subfield & 8 \\
Head/Subsection Head & 9 \\
\hline Team Member Auditors / Implementers & 20 \\
\hline \multicolumn{2}{c}{ Total }
\end{tabular}

Source: Processed by Author

Data collection is conducted through interviews, document research, and literature studies using triangulation techniques and sources (Sugiyono, 2014). The classification of informants is as follows.

Table 6.

Classification of Informants

\begin{tabular}{|c|c|c|c|}
\hline No & Classification & Description & Code \\
\hline 1 & Academics & $\begin{array}{l}\text { Lector with specifications of auditing expertise as a party that } \\
\text { provides input and criticizes academically }\end{array}$ & E1 \\
\hline 2 & Regulator & $\begin{array}{l}\text { Inspectorate VII as coordinator of data analytics } \\
\text { implementation }\end{array}$ & $\begin{array}{l}\text { A1- } \\
\text { A4 }\end{array}$ \\
\hline 3 & Practitioners & $\begin{array}{l}\text { Auditors as parties involved in the design of data analytics } \\
\text { audits as well as audit practitioners in their partners }\end{array}$ & $\begin{array}{l}\text { B1 \& } \\
\text { B2 }\end{array}$ \\
\hline \multirow[b]{2}{*}{4} & \multirow[b]{2}{*}{ Auditee } & $\begin{array}{l}\text { Directorate General of Taxation, Subdirectory related to tax } \\
\text { regulation as the affected party in terms of validity of data }\end{array}$ & $\mathrm{C} 1$ \\
\hline & & $\begin{array}{l}\text { Secretariat General, Accounting and Financial Reporting } \\
\text { Department as the affected parties in terms of business process } \\
\text { review }\end{array}$ & $\begin{array}{l}\mathrm{C} 2 \mathrm{a}- \\
\mathrm{C} 2 \mathrm{c}\end{array}$ \\
\hline \multirow{2}{*}{5} & \multirow{2}{*}{$\begin{array}{l}\text { Technical } \\
\text { Support }\end{array}$} & $\begin{array}{l}\text { Surveillance Information Systems and Human Resources } \\
\text { Source Section as parties that play a role in human resources } \\
\text { and technology }\end{array}$ & $\begin{array}{l}\text { D2- } \\
\text { D4 }\end{array}$ \\
\hline & & $\begin{array}{l}\text { Secretariat General, Center for Financial Technology } \\
\text { Information Systems as a provider of infrastructure and } \\
\text { technology }\end{array}$ & D1 \\
\hline
\end{tabular}

Source: Processed by Author

The author performs data processing using the interactive methods described by Miles dan Huberman (2014) in figure 3, with stages in the form of collection, reduction, display data, and conclusion. 
Figure 3.

Interactive Model Data Analysis Components

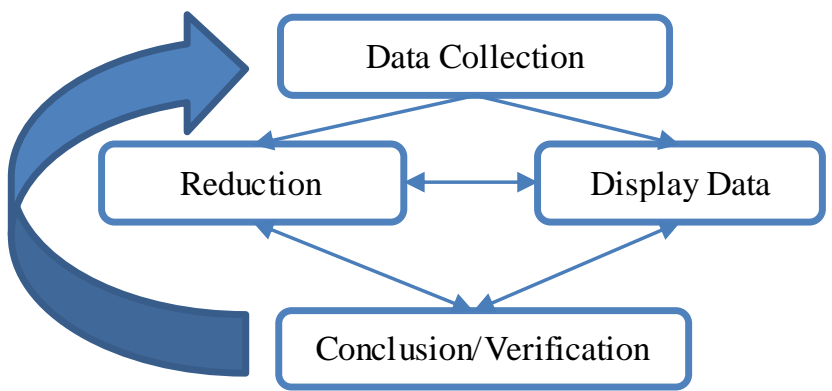

Source: (Miles dan Huberman, 2014)

The first stage is the reduction/condensation of data is the process of selecting, focusing, simplifying, abstracting, and altering the data that has been obtained and recorded in field records and intervie w transcripts - continued with the display of data, namely the process of presenting organizing, summarizing, and drafting information so that it can be drawn conclusions and appropriate actions. If the data is presented correctly, the author will understand what is obtained during the data collection. Once the data is presented, organized, and structured, then it can be concluded. The steps in the interactive method are carried out continuously until the existing data becomes saturated. The whole process is carried out considering the credibility, transferability, dependency, and affirmability of data.

\section{Results and Discussion}

\subsection{The Urgency of Analytics Data Audit Implementation}

Almost all respondents agreed that data analytics audits provide added value for both management and auditors. Management will benefit from the information processed by data analytics. At the same time, auditors benefit from micro-planning, object determination, resource efficiency, and population analysis opportunities.

It is necessary to synergize several parties to support the implementation of a data analytics audit. In general, the parties involved can be seen in business processes, development, and implementation. In terms of business processes, the parties involved include the Technical Inspectorate as the executor of the supervisory business process, 
Inspectorate VII as the coordinator and regulator, and the Information Systems and Supervision Section as the technical support unit, the Financial Technology Information System Center as the data custodian and the auditee as the data owner. A special team performs supervision and development, human resources capacity building, evaluation, and data analytics audit technical support. There are three roles in terms of implementation: data analyst, data scientist, and data operator. A data analyst is an employee who understands business processes to define the objectives of data analytics projects. Data operators process data for descriptive and diagnostic analysis needs, while data scientists process data for predictive and prescriptive analysis needs with machine learning tools.

\subsection{Analytics Data Audit Policy Model}

The concept of data analytics audit is in line with risk-based audit, as shown in Figure 4. Data analytics audit consists of Computer Assisted Audit Techniques (CAAT), $\mathrm{CA}$, and predictive analysis.

Figure 4.

Analytics Data Audit Framework

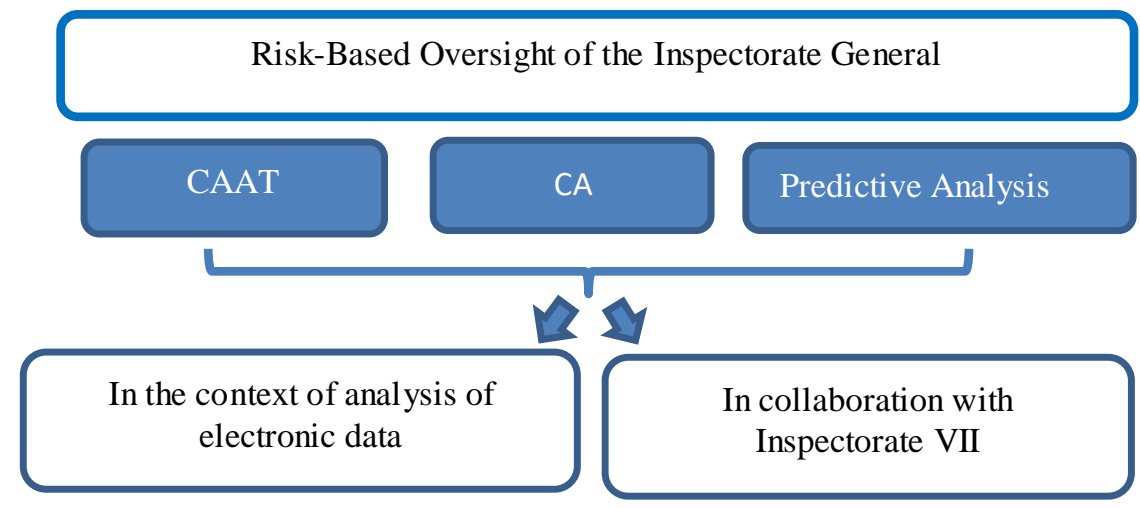

Source: Inspectorate General of the Ministry of Finance

As shown in Figure 4, in the context of analysis of electronic data, the implementation of data analytics audit is carried out by considering The Inspector General Regulation Number PER-10/IJ/2014 about Computer Assisted Audit Techniques Guidelines. In implementing data analytics audit, a collaboration between 
the Inspectorate of business processes and Inspectorate VII c.q. ICT Audit Group considers the Decree of the Inspector General Number KEP-5/IJ/2017 concerning The Implementation Guidelines of Integrated ICT Audit. A more detailed flow of risk-based audit is described in Figure 5.

Figure 5.

Risk-Based Audit Scheme with Data Analytics

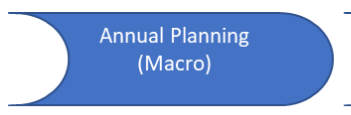

Updating Audit Universe

Identification of Key

Surveillance Areas (APU)

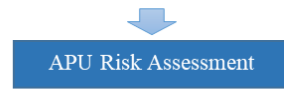

$\square$

Assurance Mapping

$\square$

Preparation of PKPT
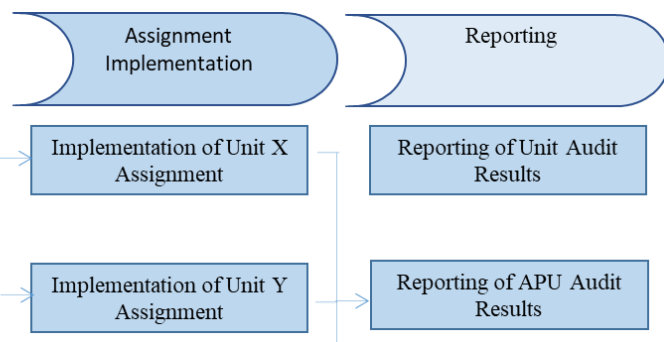

Implementation of Unit Z Assignment

Source: Inspectorate General of the Ministry of Finance

As illustrated in Figure 5, data analytics is used to test facts to conclude data (electronic) to plan and implement audit activities. In this case, data analytics includes the application of computer-assisted audit techniques (CAAT), continuous auditing/continuous monitoring $(\mathrm{CA} / \mathrm{CM})$, predictive and prescriptive analysis, and includes descriptive and unsupervised analysis. In general, the concept of data analytics audit within the framework of internal supervision is depicted in Figure 6. Various auditing techniques can be used both in macro and micro-planning, implementation, and reporting.

Predictive analysis can be used in micro-planning and execution, and descriptive, unsupervised, CA and CAAT analyses complement each other (Figure 6). The model used in the Inspectorate General is CRISP-DM which consists of business understanding, data understanding, data preparation or preprocessing, modeling, evaluation, and deployment. The concept of unsupervised analysis is currently in the technical discussion stage of its implementation. Regarding CA, if CA's output requires 
compensating control, the Inspectorate General will provide follow-up with the compensating control to the Internal Compliance Unit.

Figure 6.

Analytics Data Audit Scheme in Internal Monitoring

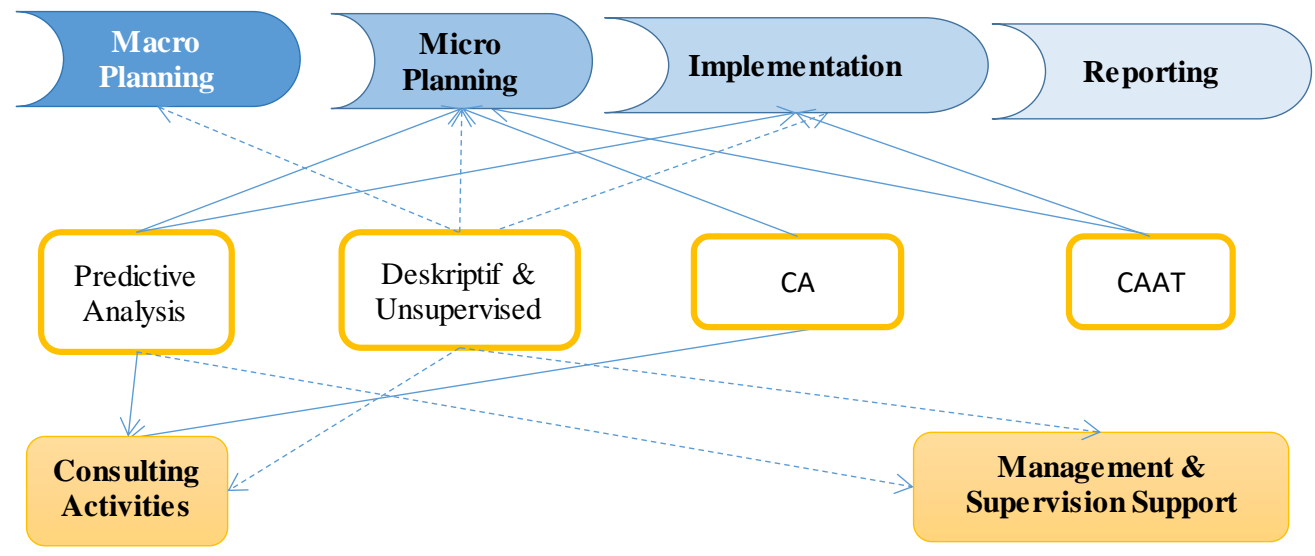

Source: Inspectorate General of the Ministry of Finance

\subsection{General Readiness}

Based on Schuh et al. (2017), organizations' readiness to implement data analytics can be reviewed from four aspects: resources readiness, information systems readiness, cultural readiness, and organizational readiness.

\subsubsection{Resources Readiness}

According to Gürdür et al. (2019), resource readiness is assessed based on three elements: infrastructure/technology, HR \&Source of power. The three elements are detailed as follows.

\subsubsection{Infrastructure and Technology}

According to Gürdür et al. (2019), organizations need to have two items, i.e., a special division that handles data analytics and has techniques and technologies for analyzing data. Discussion on special divisions or tasks of data analytics special functions has been conducted as delivered by informant A2 (intervie wed on 05/01/2020) stated, "... in the future, the data analytic division, .... will be centered in Inspectorate VII. So if that is the case, data scientists, data engineers will be positioned there. It is 
project-based, so yes..." There is a plus-minus among the choice of centralizing the business process of data analytics in one division or dividing into each Inspectorate. A centralized option has the advantage that data analytics will be more focused. However, there will be a gap between parties who understand business processes and parties who work on technical modeling and vice versa.

In terms of data analysis techniques and technology, some of the devices owned by the Inspectorate General in conducting data analytics audits include AX ACLs and Cloud servers. ACL AX is a tool to support continuous auditing and continuous monitoring that the Inspectorate General recognized in 2014. In contrast, the cloud server in the form of NAS (Network Attached Storage) can be used for shared media in a network. Info related to AX ACL from information D3-53 (interviewed on 03/01/2019), which says:

"... We have had an ACL. Until now, we also have a tool for continuous audit of an ACL called an AX ACL. It is subscribed every year, and the server is in Pusintek. On the other hand, for predictive purposes, [we] can use Python on the server [located] in Pusintek...".

From the server-side, there is a particular challenge that is the capabilities of the server. As said by Informant A2, the server's capacity to hold data from the Ministry of Finance needs to be scaled up. Besides, the maturity condition of information technology of each echelon one still varies according to informant A4. Server-related challenges were revealed by informant A2-80 (interviewed on 05/01/2020), stating:

"...challenges, in my opinion, from the outer side is the data. If infrastructure, infrastructure is not a problem. Because the organization is very supportive, actually very supportive but indeed its capability (server) does need to be upgraded.."

\subsubsection{Source of Human Power}

According to Gürdür et al. (2019), one of the indicators of human resource readiness is dedicated employees and adequate HR policies. A2 states that the composition of the organization's needs for dedicated employees is shown in table 7 with the achievements in Figure 7. 
Table 7.

HR Composition Needs for Data analytics

\begin{tabular}{|l|c|c|c|c|c|}
\hline Competency & $\mathbf{2 0 1 9}$ & $\mathbf{2 0 2 0}$ & $\mathbf{2 0 2 1}$ & $\mathbf{2 0 2 2}$ & $\mathbf{2 0 2 3}$ \\
\hline Data analyst & 8 & & 22 & \multicolumn{2}{|c|}{} \\
\hline Data scientist & 10 & 20 & 30 & 40 & 44 \\
\hline Data operator & 10 & & 44 & \multicolumn{2}{|l}{} \\
\hline
\end{tabular}

\begin{tabular}{|c|c|}
\hline & Process \\
\hline & Target met \\
\hline
\end{tabular}

Source: Processed from data analytics audit roadmap

Figure 7.

HR Achievements

\section{Data analyst}

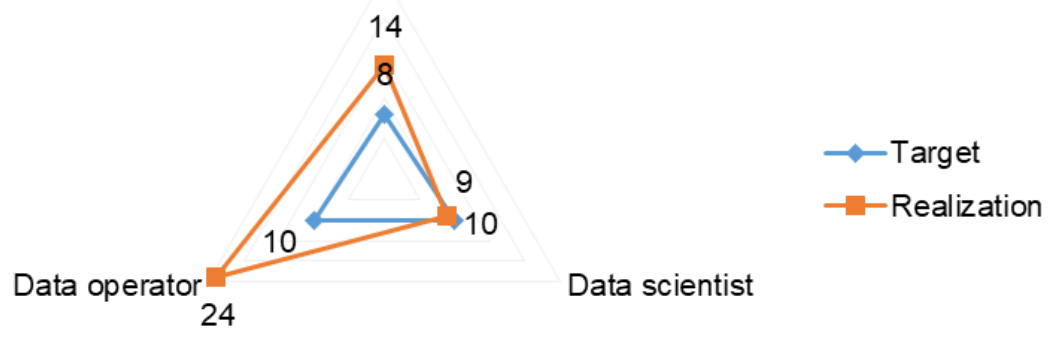

Source: Inspectorate General of the Ministry of Finance

Each competency has unique requirements following the roles and responsibilities carried out. The requirement to become a data analyst is at least being held the position of Associate Auditor and has passed the workshop data analyst for a business leader. The minimum requirement to become a data scientist is that employees have been promoted as the First Auditor or Young Auditor and have passed the data engineer training and data scientist training. While the requirement to become a data operator is that the employees have been audit team members and passed CAAT and data engineer training. The needs of dedicated employees for data analytics in 2019 have been fulfilled through human resources development, as stated in Figure 7.

In terms of HR development policy, in general, human resources development has been running well, as mentioned by informant A2. Developing human resources has been planned and implemented by preparing Training Needs Analysis (TNA), establishing competency dictionaries, and the training. The Source Human Resources (HR) division develops TNA by collaborating with the Center for Education and 
General Financial Training to support the fulfillment of competency gaps needed for data analytics audits as stated by informant D4 (interviewed on 09/01/2019):

"TNA made one year before it was implemented, then there are developments... In 2019 it was after IR VII had structured related analytic data, we went to the training center to request it as an incidental TNA, as an adjustment to the TNA that had been proposed in the previous year."

The HR department also develops competency standards to meet the needs compared to the competency gap. In general, competency standards are guided by the Regional Model Competency Standard (RMCS) and refer to The Inspector General's Decree number 270 of 2017 on Auditor Technical Competency Standards. Competency standards will always be coordinated with BPKP as the Supervisory Agency for the available position of auditor. To meet the needs of competencies, the Human Resources Department organizes education and training in data analytics. During 2019 seen in table 8, several data analytics audit training has been held. Also, there is in-house training as well as overseas training.

Table 8.

Data Analytics Education and Training

\begin{tabular}{|l|c|c|c|}
\hline \multicolumn{1}{|c|}{ Trainees } & Auditor & Non-Auditor & Total \\
\hline Data Engineer Training & 28 & 5 & 33 \\
\hline Data Scientist Training & 19 & 6 & 25 \\
\hline Data Analyst for Business Leader Workshop & 31 & 4 & 35 \\
\hline
\end{tabular}

Source: Inspectorate General of the Ministry of Finance

\subsubsection{Economy/Adequacy of Power Sources}

In terms of economics, the Inspectorate General has been carrying out budget planning audits of data analytics since T-1. The infrastructure budget is centered in Pusintek (A2), while part of the human resources development budget is coordinated with the General Financial Center (A3).

\subsubsection{Information Systems Readiness}

According to Gürdür et al. (2019), information systems readiness indicators can be assessed from data access and policies. Both aspects are in detail as follows. 


\subsubsection{Data Access}

Data access that will be discussed in this study is focused on the process of data request and data disclosure. The data exchange process has been managed by Pusintek using the Ministry of Finance Data Service System. Based on information from informant D2 (interviewed on 16/01/2020), the challenge in obtaining tax data flow is the nature of data. The other challenges are auditors' awareness of data and data services provided and understanding in defining data needs. The trend shows an increase in the data request, as shown in Figure 8.

Figure 8 .

Trend Of Surveillance Data Request

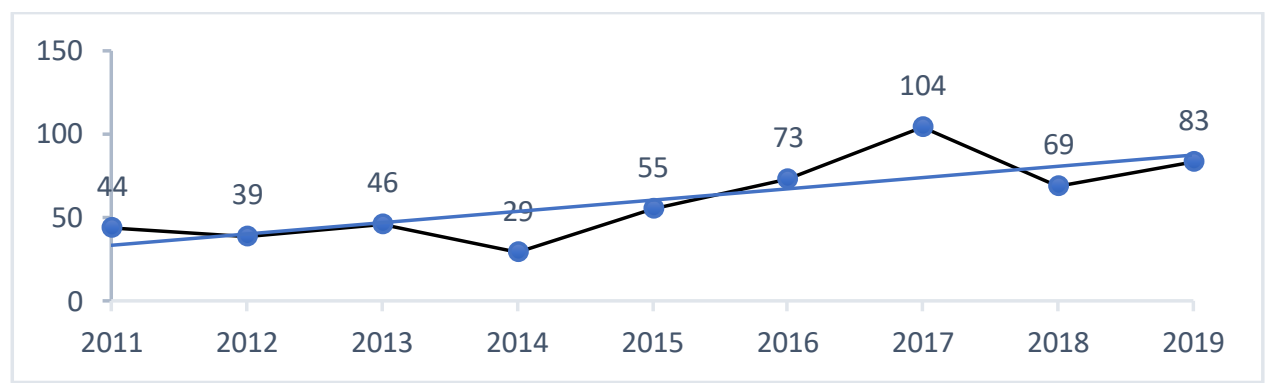

Source: Inspectorate General of the Ministry of Finance

\subsubsection{Data Analytics Policy}

The policy aspects discussed in this study focus on data utilization policies and key performance indicators. The Ministry of Finance has several data policies, such as the Decree of the Minister of Finance No. 811/KMK.01/2018 about the Ministry of Finance Data Service System, technical rules by Decree of the Director-General of Taxation Number KEP-344/PJ/2011 about Guidelines for the Implementation of Data and Information Provision in the Framework of Supervision by the Inspectorate General, Minister of Finance Regulation No. 237/PMK.09/2016 on Internal Supervision Governance in the Ministry of Finance stating that parties should utilize the information system within the Ministry of Finance. Explicitly, the Inspector General has emphasized the urgency of utilizing data exchange portals for supervision.

Inspector General builds Key Performance Indicators (KPI) about data analytics audits to encourage the implementation of data analytics audits. This KPI is outlined in 
the Inspector General Performance Contract and cascaded below it. Data analytics audit KPI includes CAAT, CA, predictive analysis, and digital forensics. Each unit has a target to implement a level 3 pilot project, meaning that the project must consistently use CAAT, CA, predictive analysis, and digital forensic tools. In 2019, all Echelon II Units in the Inspectorate General created a pilot project for data analytics audit.

\subsubsection{Culture Readiness}

Culture aspects discussed in this study are focus on perception, reward, and change management. It is necessary to be aware of the importance of data analytics audits for work and organization (Gürdür et al., 2019). The results of the interview analysis based on information from informant A4 (interviewed on 07/01/2020) are shown in table 9. The challenge related to culture readiness is building proper perception between expertise and workload.

Table 9.

Perception of Culture Readiness (In General)

\begin{tabular}{|c|c|c|c|c|c|c|c|c|c|}
\hline \multicolumn{5}{|c|}{ Perception of added value to work } & \multicolumn{5}{|c|}{ Perception of added value to the organization } \\
\hline $\begin{array}{l}\text { Informant } \\
\text { Code }\end{array}$ & A2 & A3 & A4 & $\sum$ & Informant Code & A2 & A3 & A4 & $\sum$ \\
\hline Score & 60 & 85 & 85 & 230 & Score & 85 & 75 & 50 & 210 \\
\hline \multirow{3}{*}{\multicolumn{4}{|c|}{ Average }} & \multirow{3}{*}{76,67} & Average & 85 & \multicolumn{2}{|c|}{62,5} & 147,5 \\
\hline & & & & & Weights & $60 \%$ & \multicolumn{2}{|c|}{$40 \%$} & $100 \%$ \\
\hline & & & & & Weighted Value & 51 & \multicolumn{2}{|c|}{25} & 76 \\
\hline
\end{tabular}

Source: Processed by Author

Data analytics auditing is a new method in audits. There is no doubt that changes in audit methodology in the 4.0 era will lead to various positive effects such as efficiency and effectiveness. Data scientists, data engineers, and data analysts are a necessity in the future. However, according to informant A1, A3, and A4, some challenges need to be solved organizationally by reviewing the reward mechanism.

The Inspectorate General has organized change management to perform a data analytics audit. The change management in The Inspectorate General has been done well based on change management theory by Kotter (1995) as follows. 
Table 10.

Change Management Implementation

\begin{tabular}{|c|l|l|c|}
\hline No & \multicolumn{1}{|c|}{ Change Management Theory } & \multicolumn{1}{|c|}{ Condition*) } & Result \\
\hline 1 & Establishing a Sense of Urgency & $\begin{array}{l}\text { Socialization at the leadership } \\
\text { meeting }\end{array}$ & Yes \\
\hline 2 & Forming a Powerful Guiding Coalition & Join project & Noadmap \\
\hline 3 & Creating a Vision & Intensive 2020 & Yes \\
\hline 4 & Communicating the Vision & $\begin{array}{l}\text { Empowering Others to Act on the } \\
\text { Vision and Planning for and Creating } \\
\text { Short-Term Wins }\end{array}$ & $\begin{array}{l}\text { Pilot Project, Community of } \\
\text { Practices, Rewards policy } \\
\text { (process) }\end{array}$ \\
\hline 6 & $\begin{array}{l}\text { Consolidating Improvements and } \\
\text { Producing Still More Change and } \\
\text { Institutionalizing New Approaches }\end{array}$ & $\begin{array}{l}\text { Monitoring, Evaluation, } \\
\text { Education, Training, and } \\
\text { Supervision Policy }\end{array}$ & Yes \\
\hline Change Management Process $=(3 * 100+1 * 75) / 5 * 100 \%=75 \%$ & \\
\hline
\end{tabular}

*) end of 2019

Source: Processed by Author

\subsubsection{Organizational Readiness}

According to Gürdür et al. (2019), organizational readiness indicator is assessed based on two elements: roadmap and employee trust about it is urgency. Inspectorate General has published a new roadmap related to data analytics audit because the old roadmap about CAAT toward CA has been done. The roadmap consists of three phases: the preparation phase, initiation phase, and implementation phase. The Inspectorate General has evaluated the roadmap periodically. The head of the Inspectorate General fully supports the implementation of data analytics audits by giving strategic direction. The second element of organizational readiness is employee trust in the roadmap's urgency. It is measured by interview analysis, and the result is shown in table 11 .

Table 11.

Organizational Readiness Perception (In General)

\begin{tabular}{|c|c|c|c|c|}
\hline Informant Code & $\mathrm{A} 2$ & $\mathrm{~A} 3$ & $\mathrm{~A} 4$ & $\sum$ \\
\hline Score & 20 & 75 & 25 & 120 \\
\hline Average & 20 & 50 & 70 \\
\hline Weight & $60 \%$ & $40 \%$ & $100 \%$ \\
\hline Wight Score & 12 & 20,0 & 32 \\
\hline
\end{tabular}

Source: Processed by Author 


\subsection{Specific Readiness}

Specific readiness is assessed based on the two most important business processes related to data analytics in Inspectorate General: tax audit and financial statement review. Tax audit is the duty of Inspectorate I, while the review of the financial statements is the duty of Inspectorate VI that represents Inspectorate I and Inspectorate VI. The assessment using references from Gürdür et al. (2019) customized to the Inspectorate General conditions and specific weightings to obtain relevant results. Phase one weighting is classified into three categories: looking at each phase's urgency (Table 12). Then, it is followed by weighting on every aspect in each category (Table 13).

Table 12.

Phase One Weighting Assumptions

\begin{tabular}{|l|l|r|}
\hline \multicolumn{1}{|c|}{ Phase } & \multicolumn{1}{c|}{ Category } & Weight \\
\hline Preparation phase & Short & $50 \%$ \\
\hline Initiation phase & Medium & $30 \%$ \\
\hline Deployment phase & Long & $20 \%$ \\
\hline
\end{tabular}

Source: Processed by Author

Table 13.

Phase One Weighting Mechanism

\begin{tabular}{|c|c|c|c|}
\hline Aspect & Breakdown & Type & \multirow{8}{*}{$\begin{array}{l}\text { Description } \\
\text { - "Short" means must be } \\
\text { completed in the } \\
\text { preparation phase. } \\
\text { - "Medium" means the } \\
\text { medium-term review } \\
\text { process. }\end{array}$} \\
\hline \multicolumn{3}{|c|}{ Resources Readiness } & \\
\hline \multirow{3}{*}{$\begin{array}{l}\text { Infrastructure } \\
\text { \&Technology }\end{array}$} & Special Division & Long & \\
\hline & Engineering \& technology & Short & \\
\hline & Server & Medium & \\
\hline \multirow{2}{*}{$\begin{array}{l}\text { Human } \\
\text { Resources }\end{array}$} & Dedicated person & Short & \\
\hline & Human Resources Policy & Short & \\
\hline Economic & Resources & $N / A$ & \\
\hline \multicolumn{3}{|c|}{ Information Systems Readiness } & \multirow{7}{*}{$\begin{array}{l}\text { - } \text { "Long" means } \\
\text { something needs a } \\
\text { long-term review } \\
\text { process according to } \\
\text { the organization's needs } \\
\text { (4 to } 5 \text { years. }\end{array}$} \\
\hline Data Access & Reliability of Data Access & $N / A$ & \\
\hline \multirow{2}{*}{ Policy } & Data utilization & Short & \\
\hline & Key Performance Indicator & Short & \\
\hline \multicolumn{3}{|c|}{ Cultural Readiness } & \\
\hline \multirow{2}{*}{ Perception } & Value added in work & Short & \\
\hline & Value added in an organization. & Short & \\
\hline \multirow{2}{*}{$\begin{array}{l}\text { Change } \\
\text { Management }\end{array}$} & Reward policy & Long & \multirow{5}{*}{$\begin{array}{l}\text {-N/A" means aspect } \\
\text { does not require a } \\
\text { breakdown }\end{array}$} \\
\hline & Change Management & Long & \\
\hline \multicolumn{3}{|c|}{ Organizational readiness } & \\
\hline \multirow{2}{*}{$\begin{array}{l}\text { Organisation } \\
\text { Climate }\end{array}$} & Roadmap & Long & \\
\hline & Perception of roadmap urgency & Short & \\
\hline
\end{tabular}

Source: Processed by Author 
The above weighting assumption has been consulted with experts to minimize bias. Experts also recommend additional weighting based on the informant's capacity and relevancy to the questions. Echelon IV and core team members are given $60 \%$ weight, while support team members and auditees are given $40 \%$ weight. Besides, experts also recommend phase two weighting as follows.

Table 14.

Phase Two Weighting Assumptions

\begin{tabular}{|c|c|c|c|c|}
\hline Category & Aspect & \multicolumn{2}{|c|}{ Weight } & Judgme nts \\
\hline \multirow{3}{*}{$\begin{array}{l}\text { Resources } \\
\text { Readiness }\end{array}$} & $\begin{array}{l}\text { Infrastructure } \\
\& \text { Technology }\end{array}$ & $35 \%$ & \multirow{3}{*}{$100 \%$} & \multirow{3}{*}{$\begin{array}{l}\text { The Human Resources aspect is the } \\
\text { most dynamic thing consisting of } \\
\text { competence and mindset. Next is } \\
\text { infrastructure and technology as the } \\
\text { main tools in data analytics audit } \\
\text { analysis. }\end{array}$} \\
\hline & $\begin{array}{l}\text { Human } \\
\text { Resources }\end{array}$ & $45 \%$ & & \\
\hline & Economy & $20 \%$ & & \\
\hline \multirow{2}{*}{$\begin{array}{l}\text { Information } \\
\text { Systems } \\
\text { Readiness }\end{array}$} & Data Access & $30 \%$ & \multirow{2}{*}{$100 \%$} & \multirow{2}{*}{$\begin{array}{l}\text { At the bureaucratic level, a clear } \\
\text { policy is the main thing in } \\
\text { implementing a change. }\end{array}$} \\
\hline & Policy & $70 \%$ & & \\
\hline \multirow[b]{2}{*}{$\begin{array}{l}\text { Cultural } \\
\text { Readiness }\end{array}$} & Perception & $50 \%$ & \multirow[b]{2}{*}{$100 \%$} & \multirow{2}{*}{$\begin{array}{l}\text { Both aspects have the same level of } \\
\text { importance, namely the existence of } \\
\text { policies with the support of } \\
\text { perception. }\end{array}$} \\
\hline & $\begin{array}{l}\text { Change } \\
\text { Management }\end{array}$ & $50 \%$ & & \\
\hline $\begin{array}{l}\text { Organizational } \\
\text { readiness }\end{array}$ & $\begin{array}{l}\text { Organization } \\
\text { Climate }\end{array}$ & \multicolumn{2}{|c|}{$100 \%$} & Measured in full \\
\hline
\end{tabular}

Source: Processed by Author

\subsubsection{Resources readiness}

The resources readiness category consists of three aspects: infrastructure, technology, human resources, and economy. The measurement results are stated in tables 15 and 16 for Inspectorates I and VI.

Aspects of infrastructure and technology consist of specialized divisions, techniques, and technologies for data analysis and servers. Special divisions and servers are measured at the organizational level resulting in the same number between inspectorates. The Inspectorate General is currently conducting an ongoing review of special divisions so that according to the measurement matrix, the authors classify the specific divisions at a low level or about $30 \%$. 
Table 15.

Source Readiness Level of Power Inspectorate I (Resources Readiness)

\begin{tabular}{|c|c|c|c|c|c|c|c|c|c|c|}
\hline \multirow{4}{*}{ Category } & \multicolumn{2}{|r|}{ Aspect } & \multicolumn{8}{|c|}{ Score } \\
\hline & \multirow{3}{*}{ Aspect } & \multirow{3}{*}{ Breakdown } & \multicolumn{5}{|c|}{ Breakdown Score } & \multicolumn{3}{|c|}{ Aspect Score } \\
\hline & & & \multirow{2}{*}{ Result } & \multicolumn{3}{|c|}{ Breakdown Weight } & \multirow{2}{*}{ Subtotal } & \multicolumn{2}{|c|}{ Aspek Weight } & \multirow{2}{*}{ Total } \\
\hline & & & & Category & $\%$ & Weight & & $\%$ & Weight & \\
\hline $\mathrm{a}$ & $\mathrm{b}$ & $\mathrm{c}$ & $\mathrm{d}$ & $\mathrm{e}$ & f & $\mathrm{g}=\mathrm{d} * \mathrm{f}$ & $\mathrm{h}=\sum \mathrm{g}$ & $\mathrm{i}$ & $j=h * i$ & $\mathrm{k}=\sum \mathrm{j}$ \\
\hline \multirow{6}{*}{$\begin{array}{l}\text { Resources } \\
\text { Readiness }\end{array}$} & Infrastructure & Special division & $30 \%$ & Long & $20 \%$ & $6 \%$ & \multirow{3}{*}{$49 \%$} & \multirow{3}{*}{$35 \%$} & \multirow{3}{*}{$17 \%$} & \multirow{6}{*}{$62,6 \%$} \\
\hline & \&technology & Engineering \& technology & $55 \%$ & Short & $50 \%$ & $28 \%$ & & & & \\
\hline & & Server & $50 \%$ & Medium & $30 \%$ & $15 \%$ & & & & \\
\hline & Human & Dedicated person & $83 \%$ & Short & $50 \%$ & $42 \%$ & \multirow{2}{*}{$79 \%$} & \multirow{2}{*}{$45 \%$} & \multirow{2}{*}{$36 \%$} & \\
\hline & Resource & Human resource policy & $75 \%$ & Short & $50 \%$ & $38 \%$ & & & & \\
\hline & Economic & Resources & $50 \%$ & & & & $50 \%$ & $20 \%$ & $10 \%$ & \\
\hline
\end{tabular}

Source: Processed by Author

Table 16.

Source Readiness Level of Power Inspectorate VI (Resources Readiness)

\begin{tabular}{|c|c|c|c|c|c|c|c|c|c|c|}
\hline \multirow{4}{*}{ Category } & \multicolumn{2}{|r|}{ Aspect } & \multicolumn{8}{|c|}{ Score } \\
\hline & \multirow{3}{*}{ Aspect } & \multirow{3}{*}{ Breakdown } & \multicolumn{5}{|c|}{ Breakdown Score } & \multicolumn{3}{|c|}{ Aspect Score } \\
\hline & & & \multirow{2}{*}{ Result } & \multicolumn{3}{|c|}{ Breakdown Weight } & \multirow{2}{*}{ Subtotal } & \multicolumn{2}{|c|}{ Aspek Weight } & \multirow{2}{*}{ Total } \\
\hline & & & & Category & $\%$ & Weight & & $\%$ & Weight & \\
\hline $\mathrm{a}$ & $\mathrm{b}$ & c & $\mathrm{d}$ & $\mathrm{e}$ & $\mathrm{f}$ & $g=d * f$ & $\mathrm{~h}=\sum \mathrm{g}$ & $\overline{\mathrm{i}}$ & $\mathrm{j}=\mathrm{h}^{* \mathrm{i}}$ & $\mathrm{k}=\sum \mathrm{j}$ \\
\hline \multirow{6}{*}{$\begin{array}{l}\text { Resources } \\
\text { Readiness }\end{array}$} & Infrastructure & Special division & $30 \%$ & Long & $20 \%$ & $6 \%$ & \multirow{3}{*}{$56 \%$} & \multirow{3}{*}{$35 \%$} & \multirow{3}{*}{$20 \%$} & \multirow{6}{*}{$67,7 \%$} \\
\hline & \&technology & Engineering \& technology & $70 \%$ & Short & $50 \%$ & $35 \%$ & & & & \\
\hline & & Server & $50 \%$ & Medium & $30 \%$ & $15 \%$ & & & & \\
\hline & Human & Dedicated person & $83 \%$ & \begin{tabular}{|l|} 
Short \\
\end{tabular} & $50 \%$ & $42 \%$ & \multirow{2}{*}{$79 \%$} & \multirow{2}{*}{$45 \%$} & \multirow{2}{*}{$36 \%$} & \\
\hline & Resource & Human resource policy & $75 \%$ & Short & $50 \%$ & $38 \%$ & & & & \\
\hline & Economic & Resources & $50 \%$ & & & & $50 \%$ & $25 \%$ & $13 \%$ & \\
\hline
\end{tabular}

Source: Processed by Author

Inspectorate I has defined data inspection/testing scripts and pilot data analytics projects in engineering and technology breakdown. However, it has not been automated due to data confidentiality, so the author categorizes it at the medium level (55\% score). While Inspectorate VI has been able to automate scripts and testing, the author categorizes it at a high level with a score of $70 \%$. From the server-side, Pusintek is excellent at providing servers, although it still needs scalability, so that the author categorizes it at medium level with a score of $50 \%$.

The HR aspect consists of two breakdowns: dedicated staff and adequate HR policies. The first breakdown, dedicated employees, Inspectorates I and VI have appointed dedicated employees who utilize tools (ACLs) consistently in surveillance activities. The author measures the readiness of in charge/dedicated human resources by comparing organizational needs and human resources availability. The organization 
needs to use the primary workload projection for the next five years, as found in table 17.

Table 17.

Dedicated HR Measurement

\begin{tabular}{|c|c|c|c|c|c|c|c|c|c|c|c|c|}
\hline \multirow{3}{*}{$\begin{array}{l}\text { Workload } \\
\text { Projection }\end{array}$} & \multirow{3}{*}{$\begin{array}{c}\text { Projected 5-Year } \\
\text { Workload*) }\end{array}$} & \multirow{3}{*}{ Percentage } & \multicolumn{10}{|c|}{ Dedicated Person } \\
\hline & & & \multicolumn{3}{|c|}{ Criteria } & \multirow{2}{*}{\multicolumn{3}{|c|}{\begin{tabular}{|l|}
\multicolumn{2}{|c|}{ Conditions } \\
DA DS DO
\end{tabular}}} & \multicolumn{4}{|c|}{ Percentage } \\
\hline & & & $\mathrm{DA}$ & DS & DO & & & & $\mathrm{DA}$ & DS & DO & Average \\
\hline a & $\mathrm{b}$ & $\begin{array}{c}\mathrm{c}=\mathrm{b} / \text { totalb } \\
* 100 \%\end{array}$ & $\begin{array}{c}\mathrm{d}=\text { total } \\
\mathrm{d} * \mathrm{c}\end{array}$ & $\begin{array}{c}\mathrm{e}=\text { totale } \\
*_{\mathrm{c}}\end{array}$ & $\begin{array}{c}\mathrm{f}=\text { totalf }^{*} \\
\mathrm{c}\end{array}$ & $\mathrm{g}$ & $\mathrm{h}$ & $\mathrm{i}$ & $\begin{array}{c}\mathrm{j}=\mathrm{g} / \mathrm{d} * 10 \\
0 \%\end{array}$ & $\begin{array}{c}\mathrm{k}=\mathrm{h} / \mathrm{e}^{*} 1 \\
00 \%\end{array}$ & $\begin{array}{c}\mathrm{l}=\mathrm{i} / \mathrm{f} * 100 \\
\%\end{array}$ & $\mathrm{~m}$ \\
\hline IR I & 19.642 & $18 \%$ & 2 & 3 & 3 & 1 & 3 & 3 & 0,5 & 1 & 1 & 0,83333 \\
\hline IR VI & 13.627 & $13 \%$ & 1 & 2 & 2 & 1 & 0 & 3 & 1 & 0 & 1,5 & 0,83333 \\
\hline
\end{tabular}

Note : DA (Data Analyst), DS (Data Scientist), DO (Data Operator), *) Estimated based on working group Source: Processed by Author

The second breakdown of HR is HR policy. It is measured at the organizational level so that it will produce an equal number between inspectorates. The Inspectorate General already has a competency map and training plan for employees to close the technical competency gaps. On the other hand, the competency map for data analytics has been compiled in the form of drafts so that the authors classify HR policy at the high category with a score of $75 \%$.

The economic aspect is at the organizational level to have an equal number for the entire Inspectorate. The economic aspect measures the ability of organizations to meet the financial support needed for data analytics audits both in terms of human resources and infrastructure. The Inspectorate General has established cooperation with the Pusdiklat KU to meet the needs of human resources. In terms of infrastructure, the Inspectorate General has collaborated with Pusintek in order to meet infrastructure requirements. The authors classify the economic aspects in the medium category with a score of 50\%.4.4.2 Information Systems Readiness

Table 18.

Information Systems Readiness Inspectorate I

\begin{tabular}{|c|c|c|c|c|c|c|c|c|c|c|}
\hline \multirow{4}{*}{ Category } & \multicolumn{2}{|r|}{ Aspect } & \multicolumn{8}{|c|}{ Score } \\
\hline & \multirow{3}{*}{ Aspect } & \multirow{3}{*}{ Breakdown } & \multicolumn{5}{|c|}{ Breakdown Score } & \multicolumn{3}{|c|}{ Aspect Score } \\
\hline & & & \multirow{2}{*}{ Result } & \multicolumn{3}{|c|}{ Breakdown Weight } & \multirow{2}{*}{ Subtotal } & \multicolumn{2}{|c|}{ Aspek Weight } & \multirow{2}{*}{ Total } \\
\hline & & & & Category & $\%$ & Weight & & $\%$ & Weight & \\
\hline $\mathrm{a}$ & $\mathrm{b}$ & $\mathrm{c}$ & $\mathrm{d}$ & $\mathrm{e}$ & $\mathrm{f}$ & $\mathrm{g}=\mathrm{d} * \mathrm{f}$ & $h=\sum g$ & $\mathrm{i}$ & $\mathrm{j}=\mathrm{h} * \mathrm{i}$ & $k=\sum j$ \\
\hline \multirow{3}{*}{\begin{tabular}{|l|} 
Information \\
Systems \\
Readiness
\end{tabular}} & Data access & Reliability of data access & $50 \%$ & & & & $50 \%$ & $30 \%$ & $15 \%$ & \multirow{3}{*}{$58,4 \%$} \\
\hline & \multirow[t]{2}{*}{ Data policy } & Data utilization & $50 \%$ & Short & $60 \%$ & $30 \%$ & \multirow{2}{*}{$62 \%$} & \multirow{2}{*}{$70 \%$} & \multirow{2}{*}{$43 \%$} & \\
\hline & & Key Performance Indicator & $80 \%$ & Short & $40 \%$ & $32 \%$ & & & & \\
\hline
\end{tabular}

Source: Processed by Author 
The information systems readiness category consists of two aspects: data access and policy. The measurement results are stated in table 18 .

Table 19.

Information System Readiness Level Inspectorate VI

\begin{tabular}{|c|c|c|c|c|c|c|c|c|c|c|}
\hline \multirow{4}{*}{ Category } & \multicolumn{2}{|r|}{ Aspect } & \multicolumn{8}{|c|}{ Score } \\
\hline & \multirow{3}{*}{ Aspect } & \multirow{3}{*}{ Breakdown } & \multicolumn{5}{|c|}{ Breakdown Score } & \multicolumn{3}{|c|}{ Aspect Score } \\
\hline & & & \multirow{2}{*}{ Result } & \multicolumn{3}{|c|}{ Breakdown Weight } & \multirow{2}{*}{ Subtotal } & \multicolumn{2}{|c|}{ Aspek Weight } & \multirow{2}{*}{ Total } \\
\hline & & & & Category & $\%$ & Weight & & $\%$ & Weight & \\
\hline $\mathrm{a}$ & $\mathrm{b}$ & $\mathrm{c}$ & $\mathrm{d}$ & $\mathrm{e}$ & $\mathrm{f}$ & $g=d * f$ & $h=\sum g$ & $\mathrm{i}$ & $\mathrm{j}=\mathrm{h}^{* \mathrm{i}}$ & $\mathrm{k}=\sum \mathrm{j}$ \\
\hline \multirow{3}{*}{$\begin{array}{l}\text { Information } \\
\text { Systems } \\
\text { Readiness }\end{array}$} & Data access & Reliability of data access & $70 \%$ & & & & $70 \%$ & $30 \%$ & $21 \%$ & \multirow{3}{*}{$69,4 \%$} \\
\hline & \multirow[t]{2}{*}{ Data policy } & Data utilization & $62 \%$ & Short & $60 \%$ & $37 \%$ & \multirow{2}{*}{$69 \%$} & \multirow{2}{*}{$70 \%$} & \multirow{2}{*}{$48 \%$} & \\
\hline & & Key Performance Indicator & $80 \%$ & Short & $40 \%$ & $32 \%$ & & & & \\
\hline
\end{tabular}

Source: Processed by Author

In terms of the data access aspect, during 2019, Inspectorate I has used the script to supervise VAT and tax receivables. However, Inspectorate I has not utilized population data and protocols provided by the Ministry of Finance. So far, the data acquisition is based on an assignment as stated by informant B1.c (interviewed on 31/12/2019). However, the informant B1.d (interviewed on 06/01/2020) said that the data has flowed in contrast to the above conditions. Meanwhile, the following clarification from the auditee, informant C1 (interviewed on 13/01/2020) in the legal field, states that the data is provided following the minister of finance's letter of assignment and direction. Based on this information, the authors classify the data access' aspect at the medium level with a score of $50 \%$.

While Inspectorate VI has used the script for the supervision of financial report reviews. However, Inspectorate VI has not utilized population data in surveillance clients. Centralized data acquisition protocol (standard) has been utilized with the data verification process conducted in the framework of testing. Inspectorate VI has automated scripts and testing. Based on this information, the authors classify the aspects of data access at a high level with a score of $70 \%$.

The policy aspect related to data is at the organizational level aspect, which yields an equal number for the entire Inspectorate. As described in 4.3.2.2, the Inspectorate General has policies related to the use of data and performance indicators in terms of 
policy aspects. Based on this information, the authors classify aspects of data utilization policy at the medium level with a score of $50 \%$ for Inspectorate I because the policy has not been automated and a score of $62 \%$ for Inspectorate VI because the policy has been automated. The performance indicator policy for both units is at a high level $(80 \%)$.

\subsubsection{Cultural Readiness}

The category of cultural readiness consists of two aspects: perception and change management. The measurement results are seen in table 20 for Inspectorate I and table 21 for Inspectorate VI.

Table 20.

Cultural Readiness Level of Inspectorate I

\begin{tabular}{|c|c|c|c|c|c|c|c|c|c|c|c|}
\hline \multirow{4}{*}{ Category } & \multicolumn{2}{|r|}{ Aspect } & \multicolumn{9}{|c|}{ Score } \\
\hline & \multirow{3}{*}{ Aspect } & \multirow{3}{*}{ Breakdown } & \multicolumn{6}{|c|}{ Breakdown Score } & \multicolumn{3}{|c|}{ Aspect Score } \\
\hline & & & \multirow{2}{*}{ Result } & \multicolumn{4}{|c|}{ Breakdown Weight } & \multirow{2}{*}{ Subtotal } & \multicolumn{2}{|c|}{ Aspek Weight } & \multirow{2}{*}{ Total } \\
\hline & & & & Category & & 6 & Weight & & $\%$ & Weight & \\
\hline $\mathrm{a}$ & $\mathrm{b}$ & $\mathrm{c}$ & $\mathrm{d}$ & $\mathrm{e}$ & & $\mathrm{f}$ & $\mathrm{g}=\mathrm{d} * \mathrm{f}$ & $\mathrm{h}=\sum \mathrm{g}$ & $\mathrm{i}$ & $\mathrm{j}=\mathrm{h}^{* \mathrm{i}}$ & $\mathrm{k}=\sum \mathrm{j}$ \\
\hline \multirow{4}{*}{$\begin{array}{l}\text { Cultural } \\
\text { Readiness }\end{array}$} & \multirow{2}{*}{ Perception } & Value added in work & $74 \%$ & Short & & $\%$ & $37 \%$ & \multirow{2}{*}{$73 \%$} & \multirow{2}{*}{$50 \%$} & \multirow{2}{*}{$36 \%$} & \multirow{4}{*}{$57,7 \%$} \\
\hline & & Value added in organization & $72 \%$ & Short & & $\%$ & $36 \%$ & & & & \\
\hline & Change & Reward policy & $10 \%$ & Long & $20 \%$ & $50 \%$ & $5 \%$ & \multirow{2}{*}{$43 \%$} & \multirow{2}{*}{$50 \%$} & \multirow{2}{*}{$21 \%$} & \\
\hline & Management & Change management impleme & $75 \%$ & Long & $20 \%$ & $50 \%$ & $38 \%$ & & & & \\
\hline
\end{tabular}

Source: Processed by Author

Table 21.

Cultural Readiness Level of Inspectorate VI

\begin{tabular}{|c|c|c|c|c|c|c|c|c|c|c|}
\hline \multirow{4}{*}{ Category } & \multicolumn{2}{|r|}{ Aspect } & \multicolumn{8}{|c|}{ Score } \\
\hline & \multirow{3}{*}{ Aspect } & \multirow{3}{*}{ Breakdown } & \multicolumn{5}{|c|}{ Breakdown Score } & \multicolumn{3}{|c|}{ Aspect Score } \\
\hline & & & \multirow{2}{*}{ Result } & \multicolumn{3}{|c|}{ Breakdown Weight } & \multirow{2}{*}{ Subtotal } & \multicolumn{2}{|c|}{ Aspek Weight } & \multirow{2}{*}{ Total } \\
\hline & & & & Category & \begin{tabular}{|l|}
$\%$ \\
\end{tabular} & Weight & & $\%$ & Weight & \\
\hline $\mathrm{a}$ & $\mathrm{b}$ & c & $\mathrm{d}$ & \begin{tabular}{|l|l}
$\mathrm{e}$ \\
\end{tabular} & $\mathrm{f}$ & $\mathrm{g}=\mathrm{d} * \mathrm{f}$ & $\mathrm{h}=\sum \mathrm{g}$ & i & $\mathrm{j}=\mathrm{h}^{*} \mathrm{i}$ & $k=\sum j$ \\
\hline \multirow{4}{*}{$\begin{array}{l}\text { Cultural } \\
\text { Readiness }\end{array}$} & \multirow[t]{2}{*}{ Perception } & Value added in work & $74 \%$ & Short & $50 \%$ & $37 \%$ & \multirow{2}{*}{$72 \%$} & \multirow{2}{*}{$50 \%$} & \multirow{2}{*}{$36 \%$} & \multirow{4}{*}{$57,2 \%$} \\
\hline & & Value added in organization & $70 \%$ & Short & $50 \%$ & $35 \%$ & & & & \\
\hline & Change & Reward policy & $10 \%$ & Long & \begin{tabular}{|l|l|}
$20 \%$ & $50 \%$ \\
\end{tabular} & $5 \%$ & \multirow{2}{*}{$43 \%$} & \multirow{2}{*}{$50 \%$} & \multirow{2}{*}{$21 \%$} & \\
\hline & Management & Change management implemel & $75 \%$ & Long & \begin{tabular}{|l|l|}
$20 \%$ & $50 \%$ \\
\end{tabular} & $38 \%$ & & & & \\
\hline
\end{tabular}

Source: Processed by Author

Table 22.

Cultural Readiness Analysis (value-added perception in an organization)

Inspectorate I

Value added perception in organization

\begin{tabular}{|c|c|c|c|c|c|c|}
\hline Informan Code & B1.a & B1.d & B1.b & B1.c & C1 & $\sum$ \\
\hline Score & 55 & 75 & 85 & 90 & 70 & 360 \\
\hline Average & 65 & \multicolumn{3}{|c|}{81,7} & 146,7 \\
\hline Weight & $60 \%$ & \multicolumn{3}{|c|}{$40 \%$} & $100 \%$ \\
\hline Weight score & 39 & \multicolumn{3}{|c|}{32,7} & 71,67 \\
\hline
\end{tabular}

Source: Processed by Author
Inspectorate VI

Value added perception in organization

\begin{tabular}{|c|c|c|c|c|c|c|}
\hline Informan Code & B2.b & B2.c & C2.c & C2.a & C2.b & $\sum$ \\
\hline Score & 75 & 50 & 81 & 81 & 81 & 368,0 \\
\hline Average & 62,5 & \multicolumn{2}{|c|}{81,0} & 143,5 \\
\hline Weight & $60 \%$ & \multicolumn{2}{|c|}{$40 \%$} & $100 \%$ \\
\hline Weight score & 37,5 & \multicolumn{2}{|c|}{32,4} & 69,9 \\
\hline
\end{tabular}


Table 23.

Cultural Readiness Analysis (value-added perception in work) Inspectorate I Inspectorate VI

Value added perception in work

\begin{tabular}{|c|c|c|c|c|c|c|}
\hline Informan Code & B1.a & B1.b & B1.c & B1.d & C1 & $\sum$ \\
\hline Score & 55 & 80 & 90 & 75 & 70 & 365 \\
\hline \multicolumn{7}{|c|}{ Average } \\
\hline
\end{tabular}

Value added perception in work

Source: Processed by Author

\begin{tabular}{|c|c|c|c|c|c|c|}
\hline Informan Code & B2.b & B2.c & C2.a & C2.b & C2.c & $\sum$ \\
\hline Score & 70 & 30 & 90 & 90 & 90 & 370 \\
\hline \multicolumn{7}{|c|}{ Average } \\
\hline
\end{tabular}

For the perception aspect, the author conducts interviews and categorizes informant answers in numbers based on the direction of the answers and additional questions. The results of perception analysis are found in table 22 and table 23

The change management aspect is an organizational level aspect to produce the same number for all Inspectorates both for reward and change management implementation. Both aspects have been explained in point 4.3.2. It is known that the Inspectorate General is in the process of conducting a review related to rewards. The author classifies the reward aspect in the low category. As for the change management aspect, the change management process in 2019 has been completed around $75 \%$ by analyzing documents and interview results.

\subsubsection{Organizational readiness}

The organizational readiness category consists of two aspects: roadmap and perception of roadmap urgency. The measurement results are seen in table 24 for Inspectorate I and table 25 for Inspectorate VI.

Table 24.

Level of Readiness of Inspectorate Organization I

\begin{tabular}{|c|c|c|c|c|c|c|c|c|c|c|c|}
\hline \multirow{4}{*}{ Category } & \multicolumn{2}{|r|}{ Aspect } & \multicolumn{9}{|c|}{ Score } \\
\hline & \multirow{3}{*}{ Aspect } & \multirow{3}{*}{ Breakdown } & \multicolumn{6}{|c|}{ Breakdown Score } & \multicolumn{3}{|c|}{ Aspect Score } \\
\hline & & & \multirow{2}{*}{ Result } & \multicolumn{4}{|c|}{ Breakdown Weight } & \multirow{2}{*}{ Subtotal } & \multicolumn{2}{|c|}{ Aspek Weight } & \multirow{2}{*}{ Total } \\
\hline & & & & Category & & & Weight & & $\%$ & Weight & \\
\hline $\mathrm{a}$ & $\mathrm{b}$ & $\mathrm{c}$ & $\mathrm{d}$ & \begin{tabular}{|l|}
$\mathrm{e}$ \\
\end{tabular} & & & $g=d * f$ & $\mathrm{~h}=\sum \mathrm{g}$ & $\mathrm{i}$ & $\mathrm{j}=\mathrm{h}^{* \mathrm{i}}$ & $\mathrm{k}=\sum \mathrm{j}$ \\
\hline \multirow{2}{*}{$\begin{array}{l}\text { Organizational } \\
\text { readiness }\end{array}$} & \multirow{2}{*}{$\begin{array}{l}\text { Organization } \\
\text { Climate }\end{array}$} & Roadmap & $70 \%$ & Long & $20 \%$ & $29 \%$ & $20 \%$ & \multirow[b]{2}{*}{$52 \%$} & & & \multirow[b]{2}{*}{$52,1 \%$} \\
\hline & & $\begin{array}{l}\text { Perception of roadmap } \\
\text { urgency }\end{array}$ & $45 \%$ & Short & $50 \%$ & $71 \%$ & $32 \%$ & & & & \\
\hline
\end{tabular}

Source: Processed by Author 
Table 25 .

Level of Readiness of Inspectorate Organization VI

\begin{tabular}{|c|c|c|c|c|c|c|c|c|c|c|c|}
\hline \multirow{4}{*}{ Category } & \multicolumn{2}{|r|}{ Aspect } & \multicolumn{9}{|c|}{ Score } \\
\hline & \multirow{3}{*}{ Aspect } & \multirow{3}{*}{ Breakdown } & \multicolumn{6}{|c|}{ Breakdown Score } & \multicolumn{3}{|c|}{ Aspect Score } \\
\hline & & & \multirow{2}{*}{ Result } & \multicolumn{4}{|c|}{ Breakdown Weight } & \multirow{2}{*}{ Subtotal } & \multicolumn{2}{|c|}{ Aspek Weight } & \multirow{2}{*}{ Total } \\
\hline & & & & Category & 9 & 6 & Weight & & $\%$ & Weight & \\
\hline $\mathrm{a}$ & $\mathrm{b}$ & $\mathrm{c}$ & $\mathrm{d}$ & \begin{tabular}{|l|l}
$\mathrm{e}$ \\
\end{tabular} & & $\mathrm{f}$ & $\mathrm{g}=\mathrm{d} * \mathrm{f}$ & $\mathrm{h}=\sum \mathrm{g}$ & $\mathrm{i}$ & $\mathrm{j}=\mathrm{h}^{*} \mathrm{i}$ & $\mathrm{k}=\sum \mathrm{j}$ \\
\hline \multirow{2}{*}{$\begin{array}{l}\text { Organizational } \\
\text { readiness }\end{array}$} & Organization & Roadmap & $70 \%$ & Long & $20 \%$ & $29 \%$ & $20 \%$ & \multirow[b]{2}{*}{$61 \%$} & & & \multirow[b]{2}{*}{$60,7 \%$} \\
\hline & Climate & $\begin{array}{l}\text { Perception of roadmap } \\
\text { urgency }\end{array}$ & $57 \%$ & Short & $50 \%$ & $71 \%$ & $41 \%$ & & & & \\
\hline
\end{tabular}

Source: Processed by Author

The Inspectorate General has implemented the data analytics audit roadmap, although it needs continuous improvements to cover the previous roadmap gap. So that, the authors classify the roadmap aspects as the high category at $70 \%$. The authors measured the perception of roadmap urgency through interviews with data analytics coordinators, as shown in table 26.

Table 26.

Organizational Readiness Analysis of Inspectorate I and Inspectorate VI

\begin{tabular}{|c|c|c|c|c|c|c|c|}
\hline Unit & \multicolumn{7}{|c|}{ Detail } \\
\hline \multirow{5}{*}{ Inspectorate I } & Informant Code & B1.a & B1.d & B1.b & B1.c & $\mathrm{C} 1$ & $\sum$ \\
\hline & Score & 20 & 30 & 70 & 75 & 80 & 50 \\
\hline & Average & \multicolumn{2}{|c|}{25} & \multicolumn{3}{|c|}{75} & 100 \\
\hline & Weight & \multicolumn{2}{|c|}{$60 \%$} & \multicolumn{3}{|c|}{$40 \%$} & $100 \%$ \\
\hline & Weight score & \multicolumn{2}{|c|}{15,0} & \multicolumn{3}{|c|}{30,0} & 45 \\
\hline \multirow{5}{*}{ Inspectorate VI } & Informant Code & B2.b & B2.c & C2.c & C2.a & C2.b & $\sum$ \\
\hline & Score & 61 & 21 & 81 & 81 & 81 & 325 \\
\hline & Average & \multicolumn{2}{|c|}{41} & \multicolumn{3}{|c|}{81,0} & 122 \\
\hline & Weight & \multicolumn{2}{|c|}{$60 \%$} & \multicolumn{3}{|c|}{$40 \%$} & $100 \%$ \\
\hline & Weight score & \multicolumn{2}{|c|}{24,6} & \multicolumn{3}{|c|}{32,4} & 57 \\
\hline
\end{tabular}

Source: Processed by Author

Table 27.

Comparison of Inspectorate I and VI Readiness with Target

\begin{tabular}{|l|c|c|c|c|c|c|}
\hline \multirow{2}{*}{ Category } & \multicolumn{3}{|c|}{ Inspectorate I } & \multicolumn{3}{c|}{ Inspectorate VI } \\
\cline { 2 - 7 } & $\begin{array}{c}\text { Average } \\
\text { Score }\end{array}$ & $\begin{array}{c}\text { Allignment } \\
\text { assestment }\end{array}$ & $\begin{array}{c}\text { Readiness } \\
\text { level }\end{array}$ & $\begin{array}{c}\text { Average } \\
\text { Score }\end{array}$ & $\begin{array}{c}\text { Allignment } \\
\text { ass estment }\end{array}$ & $\begin{array}{c}\text { Readiness } \\
\text { level }\end{array}$ \\
\hline Resources Readiness & $62,6 \%$ & High & 4 & $67,7 \%$ & High & 4 \\
\hline Information Systems Readiness & $58,4 \%$ & Medium & 3 & $69,4 \%$ & High & 4 \\
\hline Cultural Readiness & $57,7 \%$ & Medium & 3 & $57,2 \%$ & Medium & 3 \\
\hline Organizational readiness & $52,1 \%$ & Medium & 3 & $60,7 \%$ & Medium & 3 \\
\hline
\end{tabular}

Source: Processed by Author 
Figure 9.

Comparison Readiness Diagram

Inspectorate I

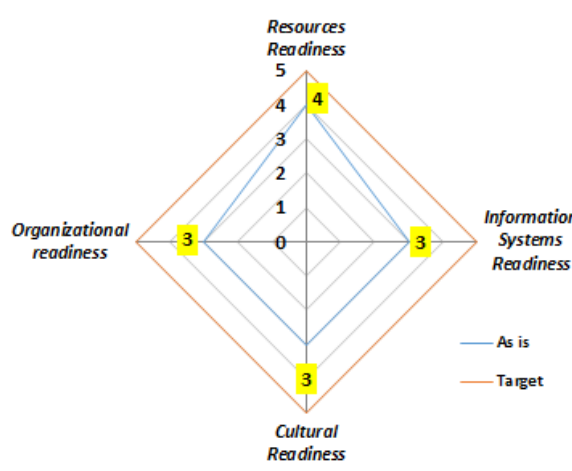

Inspectorate VI

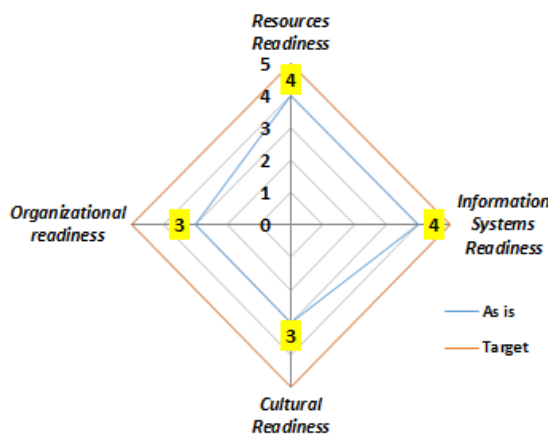

Source: Processed by Author

Based on the previous description, the readiness of Inspectorate I and Inspectorate VI can be summarized in table 27. the visualization of the readiness of Inspectorate I is illustrated in Figure 9.

\subsection{Challenges and Strategies}

There are several challenges, both internal and external. Internal challenges include management commitments and a sense of urgency, while external challenges include infrastructure and data access. Here are some strategies to address related challenges.

\subsubsection{Internal}

The supreme leader, in this case, the Inspector General, has strongly supported the data analytics audit program. Management commitments have become a challenge in itself in order to foster a solid organizational culture. Informant A2, A1, and D4 and several other sources agreed that the same mindset and sense of urgency are needed to support the success of data analytics audits. Strategic steps that can be implemented to minimize challenges include leader's talk, refocusing key performance indicators (KPI), and intensive socialization.

\subsubsection{External}

Informant A2, A1, C1, and several other informants stated that the concept of data analytics audit requires significant financial investment. Pusintek, as the unit in charge of information technology infrastructure, supports the infrastructure requirement from 
the organizational side. Further, the next challenge is the complexity of data, information security awareness, and the legality of data exchange. Strategic mitigations that can be implemented to minimize challenges include carrying out joint studies and projects between the Inspectorate General, Pusintek, and Echelon I Units, optimizing the Data Service System of the Ministry of Finance, as well as creating SOP links.

\section{Conclusion, Implication, and Limitation}

\subsection{Conclusion}

The urgency of implementing data analytics audits is due to the potential of data and the demands of GRC effectiveness. The Inspectorate General creates the policy model aligned with the concept of risk-based audits that have been carried out previously. In general, the Inspectorate General of the Ministry of Finance has reached an adequate data analytics audit readiness level. From the descriptive analysis, the category of resources readiness is at the high level while the other categories at the medium level. In particular, based on the analysis, the two most prominent business processes related to data analytics, namely tax audit, and review of financial statements, have adequate readiness levels. The readiness of data analytics audit on tax audit for resources readiness category is at a high level while other categories are at medium level. Meanwhile, the readiness of data analytics audit on the report's review for the category of resources readiness and information is high and the other categories at the medium level. The Gaps occurred due to internal and external challenges of organizations accompanied by strategic steps in the form of a data analytics audit roadmap.

\subsection{Implication and Limitation}

This research has implications as a strategy to accelerate the implementation of data analytics audit both to the Ministry of Finance and as a benchmark for other Ministries/Institutions in Indonesia. By analyzing readiness, the organization will align the organization's strategy, target, and performance. Analysis of organizational readiness in this research can be further elaborated by expanding unit samples and using quantitative or mixed methods. 


\section{Reference}

Andriansyah, Muhammad. (2019). Analisis Implementasi Continuous Audit Di Lingkungan Inspektorat Jenderal Kemenkeu. Tangerang: PKN STAN.

Armenakis, Achilles A., Stanley G. Harris, and Kevin W. Mossholder. (1993). Creating Readiness for Organizational Change. Human Relations 46. no. 6: 681-703. https://doi.org/10.1177/001872679304600601

Atan, Ruhaya, dan Fazi yatun Mohamed Yahya. (2015). Accrual Accounting Change: Malaysian Public Sector Readiness. Journal of Management Research 7, no. 2: 459. http://www.macrothink.org/journal/index.php/jmr/article/view/6978/5790

Auronen, Lauri. (2003). Asymmetric Information: Theory and Applications. In Seminar in Strategy and International Business. Helsinki University of Technology. http://citeseerx.ist.psu.edu/viewdoc/download?doi=10.1.1.198.9252\&rep=rep1\&type= pdf

Basri, Hasan, Fahlevi Heru, and Hanifa Soraya Syarifah. (2016). Determinants of Government Agencies' Readiness in Adopting Accrual Accounting System-A Study in the Local Agencies of Indonesian Ministry of Religious Affairs. Journal of Finance and Auditing Studies 2, no. 4: 60-74.

https://jafas.org/articles/2016-2-4/4_Accounting_System_FULL_TEXT.pdf

Chen, Hsinchun, Roger H L Chiang, Veda C Storey, and J Mack Robinson. (2012). Special Issues: Business Intelligence Research Business Intelligence and Analytics: From Big Data to Big Impact. MIS Quarterly 36, no. 4: 1165-88. DOI: 10.2307/41703503

Daryanto. (2019). Antisipasi Perubahan Dan Peran Auditor Pemerintah Dalam Menghadapi Revolusi Industri 4.0. Warta Pengawasan BPKP, 2019.

http://www.bpkp.go.id/public/upload/unit/pusat/files/Final\%20artikel\%201\%20tahun \%202019\%20small.pdf

Earley, Christine E. (2015). Data Analytics in Auditing: Opportunities and Challenges. Business Horizons 58, no. 5: 493-500. 10.1016/j.bushor.2015.05.002

Earnshaw, Rae, John Dill, and David Kasik. (2019). Data Science and Visual Computing. Advanced Information and Knowledge Processing. Cham: Springer International Publishing.

Fauzan, Reza. (2013). Pengaruh Kapasitas Source Daya Manusia Dan Komitmen Organisasi Terhadap Penerapan Pengendian Intern Kas Pada Satuan Kerja Perangkat Daerah Di Lingkungan Pemerintah Kota Sabang. Jurnal Akuntansi 2, no. 2: 16-27. https://docplayer.info/37598100-Jurnal-teknik-sipil-issn-pascasarjana-universitassyiah-kuala-12-pages-pp.html 
Godfrey, Jayne, Hodgson Allan, Tarca Ann, Hamilton Jane, and Holmes Scot. (2010). Accounting Theory. 7. Australia: John Wiley \& Sons Australia, Ltd.

Goodson, Stephen G, J. Mory Kenneth, and R. Lapointe Jacques. (2012). Supplemental Guidance: The Role of Auditing in Public Sector Governance.

https://globaliia.org/standards-guidance

Gürdür, Didem, Jad El-khoury, and Martin Törngren. (2019). Digitalizing Swedish Industry: What Is next? Data Analytics Readiness Assessment of Swedish Industry, According to Survey Results. Computers in Industry 105 (February): 153-63.

https://doi.org/10.1016/j.compind.2018.12.011

Hiererra, Siti, and Mario Octaviano Ignatius Sarayar. (2014). Continuous Audit: Implementasi Dan Pengendalian Berbasis Teknologi Dalam Menjalankan Fungsi Audit Yang Lebih Efektif Dan Efisien. Comtech 5, no. 2: 763-74.

https://media.neliti.com/media/publications/166166-ID-continuous-auditimplementasi-dan-pengen.pdf

Miles, B. Matthew dan A. Michael Huberman. (2014). Qualitative Data Analysis. Edisi Ketiga. California: Sage Publications.

IIA. (2016). International Standards for The Professional Practice of Internal Auditing (Standards). https://globaliia.org

Inspectorate General of the Ministry of Finance. (2018). Kerangka Pengembangan Data Analytics Inspektorat Jenderal. Jakarta: Inspectorate General of the Ministry of Finance.

International Auditing and Assurance Standards Board's (IAASB). (2017). Exploring the Growing Use of Technology in the Audit, with a Focus on Data Analytics Content. https://www.iaasb.org/publications/exploring-growing-use-technology-audit-focusdata-analytics

Kayahan. (2013). Continuous Audit: From the Concept towards the Implementation. International Journal of Business and Social Research 3, no. 7: 1-7. http://dx.doi.org/10.18533/ijbsr.v3i7.240

Kogan, Alexander, Ephraim F. Sudit, and Miklos A. Vasarhelyi. (2018). Continuous Online Auditing: A Program of Research. Journal of Information Systems 13, no. 2: 87-103. 10.1108/978-1-78743-413-420181006

Kotter, John P. (1995). Leading Change: Why Transformation Efforts Fail Harvard Business Review. Boston: Harvard Business Review. https://hbr.org/1995/05/leading-change-why-transformation-efforts-fail-2

Lambrechts, Altus J, ELourens Jacques, B Millarr Peter, and E Sparks Donald. (2011). Global Technology Audit Guide (GTAG) 16: Data Analytics Technologies. USA: Institute of Internal Auditors. https://na.theiia.org/standards-guidance/recommendedguidance/practice-guides/Pages/GTAG16.aspx 
The Indonesian Journal of Accounting Research - May, Vol. 24, No.2, 2021

Lehman, Wayne E.K., Jack M. Greener, and D. Dwayne Simpson. (2002). Assessing Organizational Readiness for Change. Journal of Substance Abuse Treatment 22, no. 4: 197-209. DOI: 10.1016/S0740-5472(02)00233-7

Liddy, James P. (2014). "The Future of Audit.".

https://www.forbes.com/sites/realspin/2014/08/04/the-future-of-audit/\#21a088e22725.

Manyika, James. 2011. Big Data: The Next Frontier for Innovation, Competition, and Productivity | McKinsey. (2011).

https://www.mckinsey.com/business-functions/mckinsey-digital/our-insights/big-datathe-next-frontier-for-innovation.

Meulen, Rob Vander, and Thomas McCall. (2018). Gartner Survey Shows Organizations Are Slow to Advance in Data and Analytics. 2018.

https://www.gartner.com/en/newsroom/press-releases/2018-02-05-gartner-surveyshows-organizations-are-slow-to-advance-in-data-and-analytics.

Russom, Philip. (2011). TWDI Best Practices Report (Fourth Quarter). https://tdwi.org/research/2011/09/ /media/TDWI/TDWI/Research/BPR/2011/TDWI BPReport_Q411_Big_Data_Analytics_Web/TDWI_BPReport_Q411_Big\%20Data_E xecSummary.ashx

Schuh, Gunther, Anderl Reiner, Jurgen Gausemier, Michael ten Hompel, and Wolfgang Wahlster. (2017). Industrie 4.0 Maturity Index. Jerman. https://www.acatech.de/wpcontent/uploads/2018/03/acatech_STUDIE_Maturity_Index_eng_WEB.pdf

Stippitch, Warren W. and Bradley. (2016). Data Analytics Elevating Internal Audit Value. Florida: The Institute of Internal Auditors Research Foundation.

Sugiyono. (2016). Metode Penelitian Kuantitatif, Kualitatif, dan R\&D. Bandung: PT Alfabeth.

World Economic Forum. (2018). The Future of Jobs Report. http://reports.weforum.org/futureof-jobs-2018. 


\section{Appendix}

Data Analytics Audit Readiness Level Measurement Matrix

\begin{tabular}{|c|c|c|c|c|c|}
\hline \multirow{2}{*}{ Code } & \multicolumn{5}{|c|}{ Indicator } \\
\hline & Very Low & Low & Medium & High & Very High \\
\hline A1.1 & \multicolumn{5}{|c|}{ Review process and consider the urgency of the output } \\
\hline A1.2 & $\begin{array}{l}\text { Simple } \\
\text { application as } \\
\text { an auditing } \\
\text { tool }\end{array}$ & $\begin{array}{l}\text { Processing } \\
\text { tools } \\
\text { data as an } \\
\text { auditing } \\
\text { tool }\end{array}$ & $\begin{array}{l}\text { Define a } \\
\text { proofing script }\end{array}$ & Automate scripts & $\begin{array}{l}\text { Automate } \\
\text { scripts and } \\
\text { ETL } \\
\text { (extraction, } \\
\text { transfer, and } \\
\text { load) }\end{array}$ \\
\hline A1.3 & $\begin{array}{l}\text { Does not have } \\
\text { a centralized } \\
\text { server yet }\end{array}$ & \multicolumn{3}{|c|}{$\begin{array}{l}\text { Already have a server (capacity needs to be } \\
\text { increased) } \\
\text { (very need-quite need-a little need) }\end{array}$} & $\begin{array}{l}\text { Already have a } \\
\text { server with } \\
\text { enough } \\
\text { capacity }\end{array}$ \\
\hline \multirow[t]{2}{*}{ A 2.1} & $\begin{array}{l}\text { No employee } \\
\text { has been able } \\
\text { to use CAAT }\end{array}$ & $\begin{array}{l}\text { Has used } \\
\text { CAAT, } \\
\text { although } \\
\text { not yet } \\
\text { consistent }\end{array}$ & $\begin{array}{l}\text { Has used } \\
\text { CAAT } \\
\text { consistently }\end{array}$ & $\begin{array}{lr}\text { Has } & \text { used } \\
\text { continuous } & \text { audit } \\
\text { tools } & \end{array}$ & $\begin{array}{l}\text { Has used data } \\
\text { analytics } \\
\text { auditing tools }\end{array}$ \\
\hline & \multicolumn{5}{|c|}{ Also, consider the aspects of fulfilling the roadmap of the preparation phase. } \\
\hline A 2.2 & $\begin{array}{l}\text { There is no } \\
\text { competency ga }\end{array}$ & $\begin{array}{l}\text { mandatory } \\
\text { fulfillment }\end{array}$ & $\begin{array}{l}\text { There has been } \\
\text { competency gap } \\
\text { mandatory level. }\end{array}$ & $\begin{array}{l}\text { the fulfillment of } \\
\text { in the advanced }\end{array}$ & $\begin{array}{l}\text { There has been } \\
\text { the fulfillment } \\
\text { of mandatory } \\
\text { competency } \\
\text { gaps at the } \\
\text { advanced level } \\
\text { related to data } \\
\text { analytics. }\end{array}$ \\
\hline A3 & No & & $\begin{array}{l}\text { Review } \\
\text { Process } \\
\end{array}$ & Yes & \\
\hline B1 & No & & $\begin{array}{l}\text { Yes, but not } \\
\text { sustainable }\end{array}$ & Yes and sustainable & \\
\hline B2.1 & $\begin{array}{l}\text { Do not yet hay } \\
\text { electronic dat } \\
\text { policy for } \\
\text { activities. }\end{array}$ & $\begin{array}{l}\text { and apply } \\
\text { utilization } \\
\text { surveillance }\end{array}$ & $\begin{array}{l}\text { Have owned } \\
\text { and } \\
\text { implemented } \\
\text { electronic data } \\
\text { request and } \\
\text { storage } \\
\text { mechanism } \\
\text { policies }\end{array}$ & $\begin{array}{l}\text { Have owned and } \\
\text { electronic data u } \\
\text { automatically }\end{array}$ & $\begin{array}{l}\text { implemented an } \\
\text { ilization policy }\end{array}$ \\
\hline B2.2 & $\begin{array}{l}\text { Do not } \\
\text { performance } \\
\text { related to the } \\
\text { electronic } \\
\text { surveillance ac }\end{array}$ & $\begin{array}{l}\text { yet have } \\
\text { indicators } \\
\text { tilization of } \\
\text { data for } \\
\text { vities }\end{array}$ & $\begin{array}{l}\text { Have } \\
\text { have } \\
\text { performance } \\
\text { indicators } \\
\text { related to the }\end{array}$ & $\begin{array}{l}\text { Has had } \\
\text { performance } \\
\text { indicators related } \\
\text { to the utilization } \\
\text { of electronic data }\end{array}$ & $\begin{array}{l}\text { Already has } \\
\text { performance } \\
\text { indicators } \\
\text { related to } \\
\text { surveillance }\end{array}$ \\
\hline
\end{tabular}


The Indonesian Journal of Accounting Research - May, Vol. 24, No.2, 2021

\begin{tabular}{|c|c|c|c|c|c|}
\hline \multirow{3}{*}{ Code } & \multicolumn{5}{|c|}{ Indicator } \\
\hline & \multirow[t]{2}{*}{ Very Low } & \multirow[t]{2}{*}{ Low } & Medium & High & Very High \\
\hline & & & $\begin{array}{l}\text { utilization of } \\
\text { electronic data } \\
\text { to } \\
\text { surveillance } \\
\text { activities }\end{array}$ & $\begin{array}{l}\text { for continuous } \\
\text { surveillance } \\
\text { activities }\end{array}$ & $\begin{array}{l}\text { activities that } \\
\text { implement data } \\
\text { analytics } \\
\text { audits. }\end{array}$ \\
\hline $\mathrm{C} 1.2$ & \multicolumn{2}{|l|}{$40 \%$} & $41 \%$ s.d. $60 \%$ & \multicolumn{2}{|l|}{$61 \%$ s.d. $100 \%$} \\
\hline C1.2 & \multicolumn{2}{|l|}{$40 \%$} & $41 \%$ s.d. $60 \%$ & \multicolumn{2}{|l|}{$61 \%$ s.d. $100 \%$} \\
\hline $\mathrm{C} 2.1$ & \multicolumn{4}{|l|}{$\begin{array}{l}\text { Do not yet } \\
\text { have policies } \\
\text { related to link } \\
\text { and match } \\
\text { performance, } \\
\text { compensation, } \\
\text { and careers } \\
\text { against data } \\
\text { analytics audit } \\
\text { actors. }\end{array}$} & $\begin{array}{l}\text { Already own } \\
\text { and apply it }\end{array}$ \\
\hline $\mathrm{C} 2.2$ & $0 \%$ & $40 \%$ & $40 \%$ s.d. $60 \%$ & $61 \%$ s.d. $80 \%$ & $81 \%$ s.d. $100 \%$ \\
\hline \multirow[b]{2}{*}{ D1 } & \multirow{2}{*}{\multicolumn{2}{|c|}{$\begin{array}{l}\text { Do not yet have a roadmap } \\
\text { of continuous audit (CA) } \\
\text { and data analytics (DA) }\end{array}$}} & \multirow{2}{*}{$\begin{array}{l}\text { Already has a } \\
\text { roadmap } \\
\text { for CA } \\
\text { implementation }\end{array}$} & $\begin{array}{l}\text { Has implemented } \\
\text { a CA road map }\end{array}$ & \multirow{2}{*}{$\begin{array}{l}\text { Has } \\
\text { implemented a } \\
\text { DA-related } \\
\text { roadmap }\end{array}$} \\
\hline & & & & $\begin{array}{l}\text { Already has a } \\
\text { roadmap for } \\
\text { apply da }\end{array}$ & \\
\hline D2 & \multicolumn{2}{|l|}{$40 \%$} & $41 \%$ s.d. $60 \%$ & \multicolumn{2}{|l|}{$61 \%$ s.d. $100 \%$} \\
\hline
\end{tabular}

Source: Processed by author interviews, inspectorate general studies, and literature studies 